\title{
A protocol for an intercomparison of biodiversity and ecosystem services models using harmonized land-use and climate scenarios
}

HyeJin Kim ${ }^{1,2}$, Isabel M. D. Rosa ${ }^{1,2}$, Rob Alkemade ${ }^{3,4}$, Paul Leadley ${ }^{5}$ George Hurtt $^{6}$, Alexander Popp ${ }^{7}$, Detlef P. van Vuuren $^{3,8}$, Peter Anthoni ${ }^{9}$, Almut Arneth ${ }^{9}$, Daniele Baisero ${ }^{10}$, Emma Caton ${ }^{11}$, Rebecca Chaplin-Kramer ${ }^{12}$, Louise Chini ${ }^{6}$, Adriana De Palma ${ }^{11}$, Fulvio Di Fulvio ${ }^{13}$, Moreno Di Marco ${ }^{14}$, Felipe Espinoza ${ }^{11}$, Simon Ferrier ${ }^{15}$, Shinichiro Fujimori ${ }^{16}$, Ricardo E. Gonzalez ${ }^{17}$, Maya Gueguen ${ }^{18}$, Carlos Guerra $^{1,2}$, Mike Harfoot ${ }^{19}$, Thomas D. Harwood ${ }^{15}$, Tomoko Hasegawa ${ }^{20}$, Vanessa Haverd ${ }^{21}$, Petr Havlík ${ }^{13}$, Stefanie Hellweg ${ }^{22}$, Samantha L. L. Hill ${ }^{11,19}$, Akiko Hirata ${ }^{23}$, Andrew J. Hoskins ${ }^{15}$, Jan H. Janse ${ }^{3,24}$, Walter Jetz ${ }^{25}$, Justin A. Johnson ${ }^{26}$, Andreas Krause ${ }^{9}$, David Leclère ${ }^{13}$, Ines S. Martins ${ }^{1,2}$, Tetsuya Matsui ${ }^{23}$, Cory Merow ${ }^{25}$, Michael Obersteiner ${ }^{13}$, Haruka Ohashi ${ }^{23}$, Benjamin Poulter ${ }^{27}$, Andy Purvis ${ }^{11,17}$, Benjamin Quesada ${ }^{9,28}$, Carlo Rondinini ${ }^{10}$, Aafke M. Schipper ${ }^{3,29}$, Richard Sharp ${ }^{12}$, Kiyoshi Takahashi ${ }^{20}$, Wilfried Thuiller ${ }^{18}$, Nicolas Titeux $^{1,30}$, Piero Visconti ${ }^{31,32}$, Christopher Ware ${ }^{15}$, Florian Wolf ${ }^{1,2}$, and Henrique M. Pereira ${ }^{1,2,33}$

${ }^{1}$ German Centre for Integrative Biodiversity Research (iDiv) Halle-Jena-Leipzig, Deutscher Platz 5e, 04103 Leipzig, Germany

${ }^{2}$ Institute of Biology, Martin Luther University Halle Wittenberg, Am Kirchtor 1, 06108 Halle (Saale), Germany

${ }^{3}$ PBL Netherlands Environmental Assessment Agency, the Hague, the Netherlands

${ }^{4}$ Environmental System Analysis Group, Wageningen University, Wageningen, the Netherlands

${ }^{5}$ Ecologie Systématique Evolution, Univ. Paris-Sud, CNRS, AgroParisTech, Université Paris-Saclay, 91400, Orsay, France

${ }^{6}$ Department of Geographical Sciences, University of Maryland, College Park, MD 20740, USA

${ }^{7}$ Potsdam Institute for Climate Impact Research (PIK), Member of the Leibniz Association, Potsdam, Germany

${ }^{8}$ Copernicus Institute for Sustainable Development, Utrecht University, Utrecht, the Netherlands

${ }^{9}$ Karlsruhe Institute of Technology, Dept. Meteorology and Climate/Atmospheric Environmental Research,

Kreuzeckbahnstr. 19, 82467 Garmisch-Partenkirchen, Germany

${ }^{10} \mathrm{C} / \mathrm{O}$ Global Mammal Assessment program, Department of Biology and Biotechnologies, Sapienza Università di Roma,

Viale dell’Univerisità 32, 00185, Rome, Italy

${ }^{11}$ Department of Life Sciences, Natural History Museum, London SW7 5BD, UK

${ }^{12}$ The Natural Capital Project, Stanford University, 371 Serra Mall, Stanford, CA 94305, USA

${ }^{13}$ International Institute for Applied Systems Analysis, Schlossplatz 1, Laxenburg 2361, Austria

${ }^{14}$ CSIRO Land and Water, GPO Box 2583, Brisbane QLD 4001, Australia

${ }^{15}$ CSIRO Land and Water, GPO Box 1700, Canberra ACT 2601, Australia

${ }^{16}$ Kyoto University, Department of Environmental Engineering, 361, C1-3, Kyoto University Katsura Campus,

Nishikyo-ku, Kyoto-city, 615-8540 Japan

${ }^{17}$ Department of Life Sciences, Imperial College London, Silwood Park, Ascot SL5 7PY, UK

${ }^{18}$ Univ. Grenoble Alpes, CNRS, Univ. Savoie Mont Blanc, Laboratoire d'Écologie Alpine (LECA), 38000 Grenoble, France

${ }^{19}$ UN Environment, World Conservation Monitoring Centre, 219 Huntingdon Road, Cambridge, CB3 ODL, UK

${ }^{20}$ Center for Social and Environmental Systems Research, National Institute for Environmental Studies (NIES), 16-2

Onogawa, Tsukuba, Ibaraki 305-8506, Japan

${ }^{21}$ CSIRO Oceans and Atmosphere, Canberra, 2601, Australia

${ }^{22}$ Institute of Environmental Engineering, ETH Zurich, 8093 Zurich, Switzerland

${ }^{23}$ Forestry and Forest Products Research Institute, Forest Research and Management Organization, 1 Matsunosato, Tsukuba, Ibaraki, 305-8687, Japan

${ }^{24}$ Netherlands Inst. of Ecology NIOO-KNAW, Wageningen, the Netherlands

${ }^{25}$ Ecology and Evolutionary Biology, Yale University, 165 Prospect St, New Haven, CT 06511, USA

${ }^{26}$ Institute on the Environment, University of Minnesota, 1954 Buford Ave. St. Paul, MN 55105, USA 
${ }^{27}$ NASA GSFC, Biospheric Science Lab., Greenbelt, MD 20771, USA

${ }^{28}$ Universidad del Rosario, Faculty of Natural Sciences and Mathematics, Kr 26 No 63B-48, Bogotá D.C, Colombia

${ }^{29}$ Institute for Water and Wetland Research, P.O. Box 9010, 6500 GL Nijmegen, the Netherlands

${ }^{30}$ Helmholtz Centre for Environmental Research - UFZ, Department of Community Ecology,

Theodor-Lieser-Strasse 4, 06210 Halle, Germany

${ }^{31}$ Institute of Zoology, Zoological Society of London, Regent's Park, London, NW1 4RY, UK

${ }^{32}$ Centre for Biodiversity and Environment Research, University College London, Gower Street, London, C1E6BT, UK

${ }^{33} \mathrm{CIBIO} / \mathrm{InBIO}$, Centro de Investigação em Biodiversidade e Recursos Genéticos, Cátedra REFER-Biodiveridade, Universidade do Porto, Campus Agrário de Vairão, R. Padre Armando Quintas, 4485-661 Vairão, Portugal

Correspondence: Henrique M. Pereira (hpereira@idiv.de) and HyeJin Kim (hyejin.kim@idiv.de)

Received: 25 April 2018 - Discussion started: 25 June 2018

Revised: 30 September 2018 - Accepted: 3 October 2018 - Published: 13 November 2018

\begin{abstract}
To support the assessments of the Intergovernmental Science-Policy Platform on Biodiversity and Ecosystem Services (IPBES), the IPBES Expert Group on Scenarios and Models is carrying out an intercomparison of biodiversity and ecosystem services models using harmonized scenarios (BES-SIM). The goals of BES-SIM are (1) to project the global impacts of land-use and climate change on biodiversity and ecosystem services (i.e., nature's contributions to people) over the coming decades, compared to the 20th century, using a set of common metrics at multiple scales, and (2) to identify model uncertainties and research gaps through the comparisons of projected biodiversity and ecosystem services across models. BES-SIM uses three scenarios combining specific Shared Socio-economic Pathways (SSPs) and Representative Concentration Pathways (RCPs) - SSP1xRCP2.6, SSP3xRCP6.0, SSP5xRCP8.6 - to explore a wide range of land-use change and climate change futures. This paper describes the rationale for scenario selection, the process of harmonizing input data for land use, based on the second phase of the Land Use Harmonization Project (LUH2), and climate, the biodiversity and ecosystem services models used, the core simulations carried out, the harmonization of the model output metrics, and the treatment of uncertainty. The results of this collaborative modeling project will support the ongoing global assessment of IPBES, strengthen ties between IPBES and the Intergovernmental Panel on Climate Change (IPCC) scenarios and modeling processes, advise the Convention on Biological Diversity (CBD) on its development of a post-2020 strategic plans and conservation goals, and inform the development of a new generation of nature-centred scenarios.
\end{abstract}

\section{Introduction}

Understanding how anthropogenic activities impact biodiversity and human societies is essential for nature conservation and sustainable development. Land-use and climate change are widely recognized as two of the main drivers of future biodiversity change (Hirsch and CBD, 2010; Maxwell et al., 2016; Sala, 2000; Secretariat of the CBD and UNEP, 2014), with potentially severe impacts on ecosystem services and ultimately human well-being (Cardinale et al., 2012; MEA, 2005). Habitat and land-use changes, resulting from past, present, and future human activities, as well as climate change, have both immediate and long-term impacts on biodiversity and ecosystem services (Graham et al., 2017; Lehsten et al., 2015; Welbergen et al., 2008). Therefore, current and future land-use projections are essential elements for assessing biodiversity and ecosystem change (Titeux et al., 2016, 2017). Climate change has already been observed to have direct and indirect impacts on biodiversity and ecosystems, which are projected to intensify by the end of the century, with potentially severe consequences for species and habitats, and, therefore, also for ecosystem functions and services (Pecl et al., 2017; Settele et al., 2015).

Global environmental assessments, such as the Millennium Ecosystem Assessment (MEA, 2005), the Global Biodiversity Outlooks (GBO), the multiple iterations of the Global Environmental Outlook (GEO), the Intergovernmental Panel on Climate Change (IPCC), and other studies have used scenarios to assess the impact of socio-economic development pathways on land use and climate and their consequences for biodiversity and ecosystem services (Jantz et al., 2015; Pereira et al., 2010). Models are used to quantify the biodiversity and ecosystem services impacts of different scenarios, based on climate and land-use projections from general circulation models (GCMs) and integrated assessment models (IAMs) (Pereira et al., 2010). These models include empirical dose-response models, species-area relationship models, species distribution models and more mech- 
anistic models such as trophic ecosystem models (Pereira et al., 2010; Akçakaya et al., 2015). So far, each of these scenario exercises has been based on a single model or a small number of biodiversity and ecosystem services models, and intermodel comparison and uncertainty analysis have been limited (IPBES, 2016; Leadley et al., 2014). The Expert Group on Scenarios and Models of the Intergovernmental Science-Policy Platform on Biodiversity and Ecosystem Services (IPBES) is addressing this gap by carrying out a biodiversity and ecosystem services model intercomparison with harmonized scenarios, for which this paper lays out the protocol.

Over the past 2 decades, IPCC has fostered the development of global scenarios to inform climate mitigation and adaptation policies. The Representative Concentration Pathways (RCPs) describe different climate futures based on greenhouse gas emissions throughout the 21 st century (van Vuuren et al., 2011). These emissions pathways have been converted into climate projections in the most recent Climate Model Inter-comparison Project (CMIP5). In parallel, the climate research community also developed the Shared Socioeconomic Pathways (SSPs), which consist of trajectories of future human development with different socio-economic conditions and associated land-use projections (Popp et al., 2017; Riahi et al., 2017). The SSPs can be combined with RCP-based climate projections to explore a range of futures for climate change and land-use change, and they are being used in a wide range of impact modeling intercomparisons (Rosenzweig et al., 2017; van Vuuren et al., 2014). Therefore, the use of the SSP-RCP framework for modeling the impacts on biodiversity and ecosystem services provides an outstanding opportunity to build bridges between the climate, biodiversity and ecosystem services communities; it has been explicitly recommended as a research priority in the IPBES assessment on scenarios and models (IPBES, 2016).

Model intercomparisons bring together different communities of practice for comparable and complementary modeling, in order to improve the comprehensiveness of the subject modeled, and to estimate uncertainties associated with scenarios and models (Frieler et al., 2015). In the last decades, various model intercomparison projects (MIPs) have been initiated to assess the magnitude and uncertainty of climate change impacts. For instance, the Inter-Sectoral Impact Model Intercomparison Project (ISI-MIP) was initiated in 2012 to quantify and synthesize climate change impacts across sectors and scales (Rosenzweig et al., 2017; Warszawski et al., 2014). The ISI-MIP aims to bridge sectors such as agriculture, forestry, fisheries, water, energy, and health with global circulation models, Earth system models (ESMs), and integrated assessment models for more integrated and impact-driven modeling and assessment (Frieler et al., 2017).

Here, we present the methodology used to carry out a BES-SIM in both terrestrial and freshwater ecosystems. The BES-SIM project addresses the following questions. (1) What are the projected magnitudes and spatial distribu- tion of biodiversity and ecosystem services under a range of land-use and climate future scenarios? (2) What is the magnitude of the uncertainties associated with the projections obtained from different scenarios and models? Although independent of the ISI-MIP, the BES-SIM has been inspired by ISI-MIP and other intercomparison projects and was initiated to address the needs of the global assessment of IPBES. We brought together 10 biodiversity models and six ecosystem functions and services models to assess impacts of land-use and climate change scenarios in the coming decades (up to 2070) and to hindcast changes to the last century (to 1900). The modeling approaches differ in several respects concerning how they treat biodiversity and ecosystem services responses to land-use and climate changes, including the use of correlative, deductive, and process-based approaches, and in how they treat spatial-scale and temporal dynamics. We assessed different classes of essential biodiversity variables (EBVs), including species populations, community composition, and ecosystem function, as well as a range of measures on ecosystem services such as food production, pollination, water quantity and quality, climate regulation, soil protection, and pest control (Pereira et al., 2010; Akçakaya et al., 2015). This paper provides an overview of the scenarios, models and metrics used in this intercomparison, and thus a roadmap for further analyses that is envisaged to be integrated into the first global assessment of the IPBES (Fig. 1).

\section{Scenario selection}

All the models included in BES-SIM used the same set of scenarios with particular combinations of SSPs and RCPs. In the selection of the scenarios, we applied the following criteria: (1) data on projections should be readily available, and (2) the total set should cover a broad range of landuse change and climate change projections. The first criterion entailed the selection of SSP-RCP combinations that are included in the ScenarioMIP protocol as part of CMIP6 (O'Neill et al., 2016), as harmonized data were available for these runs and they form the basis of the CMIP climate simulations. The second criterion implied a selection of scenarios with low and high degrees of climate change and different land-use scenarios within the ScenarioMIP set. Our final selection was SSP1 with RCP2.6 (moderate land-use pressure and low level of climate change) (van Vuuren et al., 2017), SSP3 with RCP6.0 (high land-use pressure and moderately high level of climate change) (Fujimori et al., 2017), and SSP5 with RCP8.5 (medium land-use pressure and very high level of climate change) (Kriegler et al., 2017), thus allowing us to assess a broad range of plausible futures (Table 1). Further, by combining projections of low and high anthropogenic pressure on land use with low and high levels of climate change, we can test these drivers' individual and synergistic impacts on biodiversity and ecosystem services. 


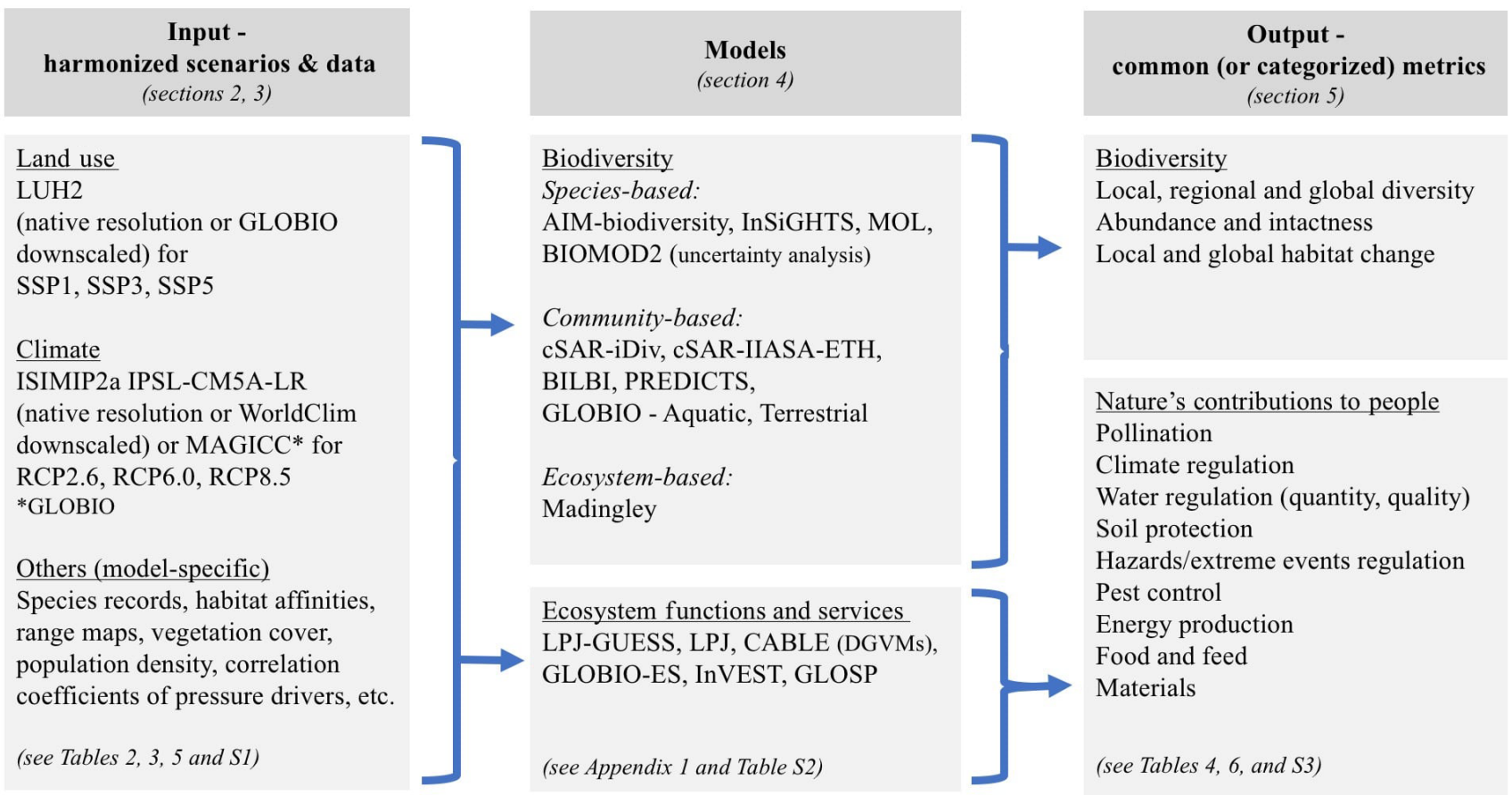

Figure 1. Input-models-output flowchart of BES-SIM.

The first scenario (SSP1xRCP2.6) is characterized by a relatively "environmentally friendly world" with low population growth, high urbanization, relatively low demand for animal products, and high agricultural productivity. These factors together lead to a decrease in the land use of around 700 Mha globally over time (mostly pastures). This scenario is also characterized by low air pollution, as policies are introduced to limit the increase in greenhouse gases in the atmosphere, leading to an additional forcing of $2.6 \mathrm{~W} \mathrm{~m}^{-2}$ before 2100. The second scenario (SSP3xRCP6.0) is characterized by "regional rivalry", with high population growth, slow economic development, material-intensive consumption, and low food demand per capita. Agricultural land intensification is low, especially due to the very limited transfer of new agricultural technologies to developing countries. This scenario has minimal land-use change regulation, with a large land conversion for human-dominated uses, and a relatively high level of climate change with a radiative forcing of $6.0 \mathrm{~W} \mathrm{~m}^{-2}$ by 2100 . The third scenario (SSP5xRCP8.5) is a world characterized by "strong economic growth" fuelled by fossil fuels, with low population growth, high urbanization, and high food demand per capita but also high agricultural productivity. As a result, there is a modest increase in land use. Air pollution policies are stringent, motivated by local health concerns. This scenario leads to a very high level of climate change with a radiative forcing of $8.5 \mathrm{~W} \mathrm{~m}^{-2}$ by 2100 . Full descriptions of each SSP scenario are provided in Popp et al. (2017) and Riahi et al. (2017). The SSP scenarios excluded elements that have interaction effects with climate change except for SSP1, which focuses on environmental sustainability. Thus, SSPs describe futures where biodiversity is not affected by climate change to allow for the important estimation of the climate change impact on biodiversity (O’Neill et al., 2014).

\section{Input data}

A consistent set of land-use and climate data was implemented across the models to the extent possible. All models in BES-SIM used the newly released Land Use Harmonization version 2 dataset (LUH2, Hurtt et al., 2018). For the models that require climate data, we selected the climate projections of the past, present, and future from CMIP5/ISIMIP2a (McSweeney and Jones, 2016) and its downscaled version from the WorldClim (Fick and Hijmans, 2017), as well as MAGICC 6.0 (Meinshausen et al., 2011a, b) from the IMAGE model for GLOBIO models (Table 2). A complete list of input datasets and variables used by the models is documented in Table S1 of the Supplement.

\subsection{Land-cover and land-use change data}

The land-use scenarios provide an assessment of landuse dynamics in response to a range of socio-economic drivers and their consequences for the land system. The IAMs used for modeling land-use scenarios - IMAGE for SSP1/RCP2.6, AIM for SSP3/RCP7.0, and REMIND/MAgPIE for SSP5/RCP8.5 - include different eco- 
Table 1. Characteristics of the (a) SSP, (b) RCP and (c) SSPxRCP scenarios simulated in BES-SIM (adapted from Moss et al., 2010; O'Neill et al., 2017; Popp et al., 2017; van Vuuren et al., 2011).

\begin{tabular}{|c|c|c|c|}
\hline (a) SSP scenarios & $\begin{array}{l}\text { SSP1 } \\
\text { Sustainability }\end{array}$ & $\begin{array}{l}\text { SSP3 } \\
\text { Regional rivalry }\end{array}$ & $\begin{array}{l}\text { SSP5 } \\
\text { Fossil-fueled development }\end{array}$ \\
\hline Population growth & Relatively low & $\begin{array}{l}\text { Low (OECD countries) to high } \\
\text { (high-fertility countries) }\end{array}$ & Relatively low \\
\hline Urbanization & High & Low & High \\
\hline Equity and social cohesion & High & Low & High \\
\hline Economic growth & High to medium & Slow & High \\
\hline International trade and globalization & Moderate & Strongly constrained & High \\
\hline Land-use regulation & $\begin{array}{l}\text { Strong to avoid environmental } \\
\text { trade-off }\end{array}$ & $\begin{array}{l}\text { Limited with continued defor- } \\
\text { estation }\end{array}$ & $\begin{array}{l}\text { Medium with slow decline in } \\
\text { deforestation }\end{array}$ \\
\hline Agricultural productivity & $\begin{array}{l}\text { High improvements with diffu- } \\
\text { sion of best practices }\end{array}$ & $\begin{array}{l}\text { Low with slow technology de- } \\
\text { velopment and restricted trade }\end{array}$ & $\begin{array}{l}\text { Highly managed and resource } \\
\text { intensive }\end{array}$ \\
\hline Consumption and diet & $\begin{array}{l}\text { Low growth in consumption, } \\
\text { low meat }\end{array}$ & $\begin{array}{l}\text { Resource-intensive consump- } \\
\text { tion }\end{array}$ & $\begin{array}{l}\text { Material-intensive consump- } \\
\text { tion, meat-rich diet }\end{array}$ \\
\hline Environment & Improving & Serious degradation & Highly successful management \\
\hline Carbon intensity & Low & High & High \\
\hline Energy intensity & Low & High & High \\
\hline Technology development & Rapid & Slow & Rapid \\
\hline Policy focus & Sustainable development & Security & $\begin{array}{l}\text { Development, free market, hu- } \\
\text { man capital }\end{array}$ \\
\hline $\begin{array}{l}\text { Participation of the land-use sector in } \\
\text { mitigation policies }\end{array}$ & Full & Limited & Full \\
\hline $\begin{array}{l}\text { International cooperation for climate } \\
\text { change mitigation }\end{array}$ & No delay & Heavy delay & Delay \\
\hline Institution effectiveness & Effective & Weak & Increasingly effective \\
\hline \multirow[t]{2}{*}{ (b) RCP scenarios } & $\mathrm{RCP} 2.6$ & RCP6.0 & RCP8.5 \\
\hline & Low emissions & Intermediate emissions & High emissions \\
\hline Radiative forcing & $\begin{array}{l}\text { Peak at } 3 \mathrm{~W} \mathrm{~m}^{-2} \text { before } 2100 \\
\text { and decline }\end{array}$ & $\begin{array}{l}\text { Stabilizes without overshoot } \\
\text { pathways to } 6 \mathrm{~W} \mathrm{~m}^{-2} \text { in } 2100\end{array}$ & $\begin{array}{l}\text { Rising forcing pathways lead- } \\
\text { ing to } 8.5 \mathrm{~W} \mathrm{~m}^{-2} \text { in } 2100\end{array}$ \\
\hline Concentration (p.p.m.) & $\begin{array}{l}\text { Peak at } 490 \mathrm{CO}_{2} \text { equiv. before } \\
2100 \text { and then declines }\end{array}$ & $\begin{array}{l}850 \mathrm{CO}_{2} \text { equiv. (at stabilization } \\
\text { after } 2100 \text { ) }\end{array}$ & $>1370 \mathrm{CO}_{2}$ equiv. in 2100 \\
\hline Methane emission & Reduced & Stable & Rapid increase \\
\hline Reliance on fossil fuels & Decline & Heavy & Heavy \\
\hline Energy intensity & Low & Intermediate & High \\
\hline Climate policies & Stringent & Very modest to almost none & High range of no policies \\
\hline \multirow[t]{2}{*}{ (c) SSPxRCP scenarios } & SSP1xRCP2.6 & SSP3xRCP6.0 & SSP5xRCP8.5 \\
\hline & Highest mitigation & Limited mitigation & No mitigation \\
\hline Bioenergy & Low & Highest & Lowest \\
\hline
\end{tabular}

nomic and land-use modules for the translation of narratives into consistent quantitative projections across scenarios (Popp et al., 2017). It is important to note that the used land-use scenarios, although driven mostly by the SSP storylines, were projected to be consistent with the paired RCPs and include biofuel deployment to mitigate climate change. The SSP3 is associated with RCP7.0 (SSP3xRCP7.0); however, climate projections (i.e., time series of precipitation and temperature) are currently not available for RCP7.0. Therefore, we chose the closest RCP available, which was RCP6.0, for the standalone use of climate projections, and chose SSP3xRCP6.0 for the land-use projections from the LUH2. In this paper, we refer to this scenario as SSP3xRCP6.0.

The land-use projections from each of the IAMs were harmonized using the LUH2 methodology. LUH2 was de- veloped for CMIP6 and provides a global gridded land-use dataset comprising estimates of historical land-use change (850-2015) and future projections (2015-2100), obtained by integrating and harmonizing land-use history with future projections of different IAMs (Jungclaus et al., 2017; Lawrence et al., 2016; O'Neill et al., 2016). Compared to the first version of the LUH (Hurtt et al., 2011), LUH2 (Hurtt et al., 2018 ) is driven by the latest SSPs, has a higher spatial resolution $\left(0.25\right.$ vs $\left.0.50^{\circ}\right)$, more detailed land-use transitions (12 versus 5 possible land-use states), and increased data-driven constraints (Heinimann et al., 2017; Monfreda et al., 2008). LUH2 provides over 100 possible transitions per grid cell per year (e.g., crop rotations, shifting cultivation, agricultural changes, wood harvest) and various agricultural management layers (e.g., irrigation, synthetic nitrogen fertilizer, biofuel 
Table 2. Improvements made in the Land Use Harmonization v2 (LUH2) from LUH v1 (sources: Hurtt et al., 2011, 2018).

\begin{tabular}{|c|c|c|}
\hline & LUH v1 & LUH v2 \\
\hline Spatial resolution & $0.5^{\circ}$ & $0.25^{\circ}$ \\
\hline Time steps & Annually from 1500 to 2100 & Annually from 850 to 2100 \\
\hline Land-use categories & $\begin{array}{l}5 \text { categories } \\
\text { - Primary } \\
\text { - Secondary } \\
\text { - Pasture } \\
\text { - Urban } \\
\text { - Crop }\end{array}$ & $\begin{array}{l}12 \text { categories } \\
\text { - Forested primary land (primf) } \\
\text { - Non-forested primary land (primn) } \\
\text { - Potentially forested secondary land (secdf) } \\
\text { - Potentially non-forested secondary land (secdn) } \\
\text { - Managed pasture (pastr) } \\
\text { - Rangeland (range) } \\
\text { - Urban land (urban) } \\
-\mathrm{C}_{3} \text { annual crops (c3ann) } \\
-\mathrm{C}_{3} \text { perennial crops (c3per) } \\
-\mathrm{C}_{4} \text { annual crops (c4ann) } \\
-\mathrm{C}_{4} \text { perennial crops (c4per) } \\
-\mathrm{C}_{3} \text { nitrogen-fixing crops (c3nfx) }\end{array}$ \\
\hline Future & $\begin{array}{l}\text { RCPs (4) } \\
- \text { RCP2.6 } \\
- \text { RCP4.5 } \\
\text { - RCP6.0 } \\
\text { - RCP8.5 }\end{array}$ & $\begin{array}{l}\text { SSPs (6) } \\
\text { - SSP1-RCP2.6 } \\
\text { - SSP4-RCP3.4 } \\
\text { - SSP2-RCP4.5 } \\
\text { - SSP4-RCP6.0 } \\
\text { - SSP3-RCP7.0 } \\
\text { - SSP5-RCP8.5 }\end{array}$ \\
\hline Land-use transitions & $<20$ per grid cell per year & $>100$ per grid cell per year \\
\hline Improvements & & $\begin{array}{l}\text { - New shifting cultivation algorithm } \\
\text { - Landsat forest/non-forest change constraint } \\
\text { - Expanded diagnostic package } \\
\text { - New historical wood harvest reconstruction } \\
\text { - Agricultural management layers: irrigation, fertilizer, biofuel crops, } \\
\text { wood harvest product split, crop rotations, flooded (rice) }\end{array}$ \\
\hline
\end{tabular}

crops), all with annual time steps. The 12 land states include the separation of primary and secondary natural vegetation into forest and non-forest sub-types, pasture into managed pasture and rangeland, and cropland into multiple crop functional types $\left(\mathrm{C}_{3}\right.$ annual, $\mathrm{C}_{3}$ perennial, $\mathrm{C}_{4}$ annual, $\mathrm{C}_{4}$ perennial, and $N$-fixing crops) (Table 2 ).

For biodiversity and ecosystem services models that rely on discrete, high-resolution land-use data (i.e., the GLOBIO model for terrestrial biodiversity and the InVEST model), the fractional LUH2 data were downscaled to discrete land-use grids (10 arcsec resolution; $\sim 300 \mathrm{~m}$ ) with the land-use allocation routine of the GLOBIO4 model. To that end, urban, cropland, pasture, rangeland, and forestry areas from LUH2 were first aggregated across the LUH2 grid cells to the regional level of the IMAGE model, with forestry consisting of the wood harvest from forested cells and nonforested cells with primary vegetation. Next, the totals per region were allocated to $300 \mathrm{~m}$ cells with the GLOBIO4 land allocation routine, with specific suitability layers for urban, cropland, pasture, rangeland, and forestry areas. After allo- cation, cropland was reclassified into three intensity classes (low, medium, high) based on the amount of fertilizer used per grid cell. More details on the downscaling procedure are provided in Supplementary Methods in the Supplement.

\subsection{Climate data}

GCMs are based on fundamental physical processes (e.g., conservation of energy, mass, and momentum and their interaction with the climate system) and simulate climate patterns of temperature, precipitation, and extreme events on a large scale (Frischknecht et al., 2016). Some GCMs now incorporate elements of Earth's climate system (e.g., atmospheric chemistry, soil and vegetation, land and sea ice, carbon cycle) in Earth system models (GCMs with an interactive carbon cycle), and have dynamically downscaled models with higher-resolution data in regional climate models (RCMs).

A large number of climate datasets are available today from multiple GCMs, but not all GCMs provide projections for all RCPs. In BES-SIM, some models require continuous 
Table 3. Sources of land-use and climate input data in BES-SIM.

\begin{tabular}{|c|c|c|c|c|c|}
\hline \multirow[t]{3}{*}{ BES-SIM model } & \multicolumn{2}{|c|}{ Land-use data } & \multicolumn{3}{|c|}{ Climate data } \\
\hline & \multirow{2}{*}{$\begin{array}{l}\text { LUH2 v2.0 native } \\
\text { resolution } 0.25^{\circ}\end{array}$} & LUH2 v2.0 downscaled & ISIMIP2a IPSL-CM5A-LR & \multirow{2}{*}{$\begin{array}{l}\text { ISIMIP2a IPSL-CM5A-LR } \\
\text { downscaled (WorldClim) } 1 \mathrm{~km}\end{array}$} & \multirow{2}{*}{$\begin{array}{c}\text { IMAGE }^{1} \\
\left(\text { MAGICC 6.0) }^{2}\right.\end{array}$} \\
\hline & & (GLOBIO) $\quad 300 \mathrm{~m}$ & native resolution $0.5^{\circ}$ & & \\
\hline \multicolumn{6}{|c|}{ Species-based models of biodiversity } \\
\hline AIM-biodiversity & $*$ & & $*$ & & \\
\hline InSiGHTS & * & & & $*$ & \\
\hline MOL & $*$ & & & $*$ & \\
\hline \multicolumn{6}{|c|}{ Community-based models of biodiversity } \\
\hline cSAR-iDiv & * & & & & \\
\hline cSAR-IIASA-ETH & * & & & & \\
\hline BILBI & * & & & * & \\
\hline PREDICTS & * & & & & \\
\hline GLOBIO - Aquatic & * & & & & $*$ \\
\hline GLOBIO4 - Terrestrial & & $*$ & & & $*$ \\
\hline \multicolumn{6}{|c|}{ Ecosystems-based model of biodiversity } \\
\hline Madingley & $*$ & & $*$ & & \\
\hline \multicolumn{6}{|c|}{ Models of ecosystem functions and services } \\
\hline LPJ-GUESS & * & & $*$ & & \\
\hline LPJ & * & & * & & \\
\hline CABLE & * & & * & & \\
\hline GLOBIO-ES & * & & & & * \\
\hline InVEST & & $*$ & & * & \\
\hline GLOSP & * & & $*$ & & \\
\hline
\end{tabular}

${ }^{1}$ All GLOBIO models use MAGICC climate data from the IMAGE model.

time-series data. In order to harmonize the climate data to be used across biodiversity and ecosystem services models, we chose the bias-corrected climate projections from CMIP5, which were also adopted by ISIMIP2a (Hempel et al., 2013) or their downscaled versions available from WorldClim (Fick and Hijmans, 2017). Most analyses were carried out using a single GCM, the IPSL-CM5A-LR (Dufresne et al., 2013), since it provides mid-range projections across the five GCMs (HadGEM2-ESGFDL-ESM2M, IPSL-CM5A-LR, MIROCESM-CHEM, and NorESM1-M) in ISIMIP2a (Warszawski et al., 2014).

The ISIMIP2a output from the IPSL-CM5A-LR provides 12 climate variables on daily time steps from the pre-industrial period 1951 to 2099 at $0.5^{\circ}$ resolution (McSweeney and Jones, 2016), of which only a subset was used in this exercise (Table S1). The WorldClim downscaled dataset has 19 bioclimatic variables derived from monthly temperature and rainfall from 1960 to 1990 with multi-year averages for specific points in time (e.g., 2050, 2070) up to 2070. Six models in BES-SIM used the ISIMIP2a dataset and three models used the WorldClim dataset. An exception was made for the GLOBIO models, which used MAGICC 6.0 climate data (Meinshausen et al., 2011a, b) in the IMAGE model framework (Stehfest et al., 2014), to which GLOBIO is tightly connected (Table 3 ). The variables used from the climate dataset in each model are listed in Table S1.

\subsection{Other input data}

In addition to the land-use and climate data, most models use additional input data to run their future and past simulations to estimate changes in biodiversity and ecosystem services. For instance, species occurrence data are an integral part of modeling in 6 of 10 biodiversity models, while 2 models rely on estimates of habitat affinity coefficients (e.g., reductions in species richness in a modified habitat relative to the pristine habitat) from the PREDICTS model (Newbold et al., 2016; Purvis et al., 2018). In three dynamic global vegetation models (DGVMs), atmospheric $\mathrm{CO}_{2}$ concentrations, irrigated fraction, and wood harvest estimates are commonly used, while two ecosystem services models rely on topography and soil-type data for soil erosion measures. A full list of model-specific input data is given in Table $\mathrm{S} 1$.

\section{Models in BES-SIM}

Biodiversity and ecosystem services models at the global scale have increased in number and improved considerably over the last decade, especially with the availability of biodiversity data and advancement in statistical modeling tools and methods (IPBES, 2016). In order for a model to be included in BES-SIM, it had either to be published in a peer-reviewed journal or adopt published methodologies, with modifications made to modeling sufficiently docu- 
mented and accessible for review (Table S2). Sixteen models were included in BES-SIM (Appendix A, details on modeling methods in Table S2). These models were mainly grouped into four classes: species-based, community-based, and ecosystem-based models of biodiversity, and models of ecosystem functions and services. The methodological approaches, the taxonomic or functional groups, the spatial resolution and the output metrics differ across models (Appendix A). All 16 models are spatially explicit, with 15 of them using land-use data as an input and 13 of them requiring climate data. We also used one model, BIOMOD2 (Thuiller, 2004; Thuiller et al., 2009), to assess the uncertainty of climate range projections without the use of land-use data.

\subsection{Species-based models of biodiversity}

Species-based models aim to predict historical, current, and future potential distribution and abundance of individual species. These can be developed using correlative methods based on species observation and environmental data (Aguirre-Gutiérrez et al., 2013; Guisan and Thuiller, 2005; Guisan and Zimmermann, 2000) as well as expert-based solutions where data limitations exist (Rondinini et al., 2011). Depending on the methodologies employed and the ecological aspects modeled, they can be known as species distribution models, ecological niche models, bioclimatic envelope models, and habitat suitability models (Elith and Leathwick, 2009). Such species-based models have been used to forecast environmental impacts on species distribution and status.

In BES-SIM, four species-based models were included: AIM-biodiversity (Ohashi et al., 2018), InSiGHTS (Rondinini et al., 2011; Visconti et al., 2016), MOL (Jetz et al., 2007; Merow et al., 2013), and BIOMOD2 (Appendix A, Table S2). The first three models project individual species distributions across a large number of species by combining projections of climate impacts on species ranges with projections of land-use impacts on species ranges. AIMbiodiversity uses Global Biodiversity Information Facility (GBIF) species occurrence data on 9025 species across five taxonomic groups (amphibians, birds, mammals, plants, reptiles) to train statistical models for current land use and climate to project future species distributions. InSiGHTS uses species' presence records from regular sampling within species' ranges and pseudo-absence records from regular sampling outside of species' ranges on 2827 species of mammals. MOL uses species land-cover preference information and species presence and absence predictions on 20833 species of amphibians, birds, and mammals. InSiGHTS and MOL rely on IUCN's range maps as a baseline, which are developed based on expert knowledge of the species habitat preferences and areas of non-occurrence (Fourcade, 2016). Both models use a hierarchical approach with two steps: first, a statistical model trained on current species ranges is used to assess future climate suitability within species ranges; second, a model detailing associations between species and habitat types based on expert opinion is used to assess the impacts of land use in the climate-suitable portion of the species range. BIOMOD2 is an $\mathrm{R}$ modeling package that runs up to nine different algorithms (e.g., random forests, logistic regression) of species distribution models using the same data and the same framework. BIOMOD2 included three taxonomic groups (amphibians, birds, mammals) (see Sect. 7 "Uncertainties").

\subsection{Community-based models of biodiversity}

Community-based models predict the assemblage of species using environmental data and assess changes in community composition through species presence and abundance (D'Amen et al., 2017). Output variables of community-based models include assemblage-level metrics, such as the proportion of species persisting in a landscape, mean species abundances (number of individuals per species), and compositional similarity (pairwise comparison at the species level) relative to a baseline (typically corresponding to a pristine landscape).

Three models in BES-SIM - cSAR-iDiv (Martins and Pereira, 2017), cSAR-IIASA-ETH (Chaudhary et al., 2015), and BILBI (Hoskins et al., 2018; Ferrier et al., 2004, 2007) - rely on versions of the species-area relationship (SAR) to estimate the proportion of species persisting in humanmodified habitats relative to native habitat (i.e., the number of species in the modified landscape divided by the number of species in the native habitat). In its classical form, the SAR describes the relationship between the area of native habitat and the number of species found within that area. The countryside SAR (cSAR) builds on the classic SAR but accounts for the differential use of both human-modified and native habitats by different functional species groups. Both the cSAR-iDiv and cSAR-IIASA-ETH models use habitat affinities (proportion of area of a habitat type that can be effectively used by a species group) to weight the areas of the different habitats in a landscape. The habitat affinities are calibrated from field studies by calculating the change in species richness in a modified habitat relative to the native habitat. The habitat affinities of the cSAR-iDiv model are estimated from the PREDICTS dataset (Hudson et al., 2017, 2016) while the habitat affinities of cSAR-IIASA-ETH come from a previously published database of studies (Chaudhary et al., 2015). The cSAR-iDiv model considers 9853 species for one taxonomic group (birds) in two functional groups (forest species and non-forest species) while cSAR-IIASAETH considers a total of 1911583 species for five taxonomic groups (amphibians, birds, mammals, plants, reptiles) by ecoregions (these are, however, not 1911583 unique species as a species present in two ecoregions will be counted twice). BILBI couples application of the species-area relationship with correlative statistical modeling of continuous spatial turnover patterns in the species composition of communities as a function of environmental variation. Through space- 
for-time projection of compositional turnover (i.e., change in species), this coupled model enables the effects of both climate change and habitat modification to be considered in estimating the proportion of species persisting for 254145 vascular plant species globally.

Three community-based models - PREDICTS, GLOBIO Aquatic (Alkemade et al., 2009; Janse et al., 2015), and GLOBIO Terrestrial (Alkemade et al., 2009; Schipper et al., 2016) - estimate a range of assemblage-level metrics based on empirical dose-response relationships between pressure variables (e.g., land-use change and climate change) and biodiversity variables (e.g., species richness or mean species abundance) (Appendix A). PREDICTS uses a hierarchical mixed-effects model to assess how a range of site-level biodiversity metrics respond to land use and related pressures, using a global database of 767 studies, including over 32000 sites and 51000 species from a wide range of taxonomic groups (Hudson et al., 2017, 2016). GLOBIO is an integrative modeling framework for aquatic and terrestrial biodiversity that builds upon correlative relationships between biodiversity intactness and pressure variables, established with meta-analyses of biodiversity data retrieved from the literature on a wide range of taxonomic groups.

\subsection{Ecosystem-based model of biodiversity}

The Madingley model (Harfoot et al., 2014b) is a mechanistic individual-based model of ecosystem structure and function. It encodes a set of fundamental ecological principles to model how individual heterotrophic organisms with a body size greater than $10 \mu \mathrm{g}$ that feed on other living organisms interact with each other and with their environment. The model is general in the sense that it applies the same set of principles for any ecosystem to which it is applied, and is applicable across scales from local to global. To capture the ecology of all organisms, the model adopts a functional trait-based approach with organisms characterized by a set of categorical traits (feeding mode, metabolic pathway, reproductive strategy, and movement ability), as well as continuous traits (juvenile, adult, and current body mass). Properties of ecological communities emerge from the interactions between organisms, influenced by their environment. The functional diversity of these ecological communities can be calculated, as well as the dissimilarity over space or time between communities (Table S2). Madingley uses three functional groups (trophic levels, metabolic pathways, and reproductive strategies).

\subsection{Models of ecosystem functions and services}

In order to measure ecosystem functions and services, three DGVM models - LPJ-GUESS (Lindeskog et al., 2013; Olin et al., 2015; Smith et al., 2014), LPJ (Poulter et al., 2011; Sitch et al., 2003), and CABLE (Haverd et al., 2018) - and three ecosystem services models - InVEST (Sharp et al.,
2016), GLOBIO (Alkemade et al., 2009, 2014; Schulp et al., 2012), and GLOSP (Guerra et al., 2016) - were engaged in this model intercomparison. The DGVMs are process-based models that simulate responses of potential natural vegetation and associated biogeochemical and hydrological cycles to changes in climate and atmospheric $\mathrm{CO}_{2}$ and disturbance regimes (Prentice et al., 2007). Processes in anthropogenically managed land (cropland, pastures, and managed forests) are also increasingly being accounted for (Arneth et al., 2017). DGVMs can project changes in future ecosystem states (e.g., type of plant functional trait (PFT), relative distribution of each PFT, biomass, height, leaf area index, water stress), ecosystem functioning (e.g., moderation of climate, processing/filtering of waste and toxicants, provision of food and medicines, modulation of productivity, decomposition, biogeochemical and nutrient flows, energy, matter, water), and habitat structure (i.e., amount, composition, and arrangement of physical matter that describe an ecosystem within a defined location and time); however, DGVMs are limited in capturing species-level biodiversity change because vegetation is represented by a small number of plant functional types (PFTs) (Bellard et al., 2012; Thuiller et al., 2013).

The InVEST suite includes 18 models that map and measure the flow and value of ecosystem goods and services across a landscape or a seascape. They are based on biophysical processes of the structure and function of ecosystems, and they account for both supply and demand. The GLOBIO model estimates ecosystem services based on outputs from the IMAGE model (Stehfest et al., 2014), the PCRaster Global Water Balance global hydrological model (PCRGLOBWB, van Beek et al., 2011), and the Global Nutrient Model (Beusen et al., 2015). It is based on correlative relationships between ecosystem functions and services, and particular environmental variables (mainly land use), quantified based on literature data. Finally, GLOSP is a 2-D model that estimates the level of global and local soil erosion, and protection using the Universal Soil Loss Equation.

\section{Output metrics}

Given the diversity of modeling approaches, a wide range of biodiversity and ecosystem services metrics can be produced by the model set (Table S2). For the biodiversity model intercomparison analysis, three main categories of common output metrics were reported over time: extinctions as absolute change in species richness ( $N$, number of species) or as proportional species richness change ( $P, \%$ species), abundance-based intactness ( $I, \%$ intactness), and mean proportional change in suitable habitat extent across species $(H$, $\%$ suitable habitat) (Table 4$)$. These metrics were calculated at two scales: local or grid cell ( $\alpha$ scale, i.e., the value of the metric within the smallest spatial unit of BES-SIM which is the grid cell) and regional or global scale ( $\gamma$ scale, i.e., the value of the metric for a set of grid cells comprising a 
Table 4. Selected output indicators for intercomparison of biodiversity and ecosystems models. For species diversity change, both proportional changes in species richness $(P)$ and absolute changes $(N)$ are reported. Some models project the $\alpha$ metrics at the level of the grid cell (e.g., species-based and SAR based community models) while others average the local values of the metrics across the grid cell weighted by the area of the different habitats in the cell (e.g., PREDICTS, GLOBIO).

\begin{tabular}{|c|c|c|c|c|}
\hline $\begin{array}{l}\text { BES-SIM } \\
\text { model }\end{array}$ & $\begin{array}{l}\text { Species diversity change } \\
\text { at local scale } \\
(P \alpha \text { and } N \alpha)\end{array}$ & $\begin{array}{l}\text { Species diversity change } \\
\text { at subregional and global scale } \\
(P \gamma \text { and } N \gamma)\end{array}$ & $\begin{array}{l}\text { Abundance-based intactness } \\
\text { at local scale } \\
(I \alpha)\end{array}$ & $\begin{array}{c}\text { Mean habitat extent change } \\
\text { at local and global scale } \\
\qquad(H \alpha \text { and } H \gamma)\end{array}$ \\
\hline \multicolumn{5}{|c|}{ Species-based models of biodiversity } \\
\hline AIM-biodiversity & $*$ & $*$ & & $*$ \\
\hline InSiGHTS & $*$ & $*$ & & $*$ \\
\hline MOL & $*$ & $*$ & & $*$ \\
\hline \multicolumn{5}{|c|}{ Community-based models of biodiversity } \\
\hline cSAR-iDiv & $*$ & $*$ & & \\
\hline cSAR-IIASA-ETH & $*$ & $*$ & & \\
\hline BILBI & & $*$ & & \\
\hline PREDICTS & $*$ & & $*$ & \\
\hline GLOBIO - Aquatic & & & $*$ & \\
\hline GLOBIO - Terrestrial & & & $*$ & \\
\hline \multicolumn{5}{|c|}{ Ecosystems-based model of biodiversity } \\
\hline Madingley & & & * & \\
\hline
\end{tabular}

region). For species richness change, some models project the $\alpha$ metrics at the grid cell level (e.g., species-based and SAR-based community models), while others average the local point values of the metrics across the grid cell weighted by the area of the different habitats in the cell (e.g., PREDICTS, GLOBIO). In addition, some models only provided $\alpha$ values while others provided both $\alpha$ and $\gamma$ values (Table 4). For the models that can project $\gamma$ metrics, both regional- $\gamma$ for each IPBES regions (Table 1 in Brooks et al., 2016; UNEPWCMC, 2015) and a global- $\gamma$ were reported.

The species diversity change metrics measured as absolute number or percentage change in species richness show species persistence and extinction in a given time and place. Absolute changes in species richness and proportional species richness change are interrelated and may be calculated from reporting species richness over time, as $N_{t}=$ $S_{t}-S_{t 0}$ and $P=N_{t} / S_{t 0}$, where $S_{t}$ is the number of species at time $t$. Most models reported one or both types of species richness metrics (Table 4). The abundance-based intactness (I) measures the mean species abundance in the current community relative to the abundances in a pristine community. This metric is available only for two community-based models: GLOBIO (where intactness is estimated as the arithmetic mean of the abundance ratios of the individual species, whereby ratios $>1$ are set to 1 ) and PREDICTS (where intactness is estimated as the ratios of the sum of species abundances). The habitat change $(H)$ measures cell-wise changes in available habitat for the species. It represents the changes in the suitable habitat extent of each species relative to a baseline, i.e., $\left(E_{i, t}-E_{i, t 0}\right) / E_{i, t 0}$, where $E_{i, t}$ is the suitable habitat extent of species $i$ at time $t$ within the unit of analysis. It is reported by averaging across species occurring in each unit of analysis (grid cell, region, or globe), and is provided by the species-level models (i.e., AIM-biodiversity, InSiGHTS, MOL) (Table 4). The baseline year, $t_{0}$, used to calculate changes for the extinction and habitat extent metrics, was the first year of the simulation (in most cases $t_{0}=1900$; see Table 5).

For ecosystem functions and services, each model's output metrics were mapped onto the new classification of Nature's Contributions to People (NCP) published by the IPBES scientific community (Díaz et al., 2018). Among the 18 possible NCPs, the combination of models participating in BESSIM was able to provide measures for $10 \mathrm{NCPs}$, including regulating metrics on pollination (e.g., proportion of agricultural lands whose pollination needs are met, \% agricultural area), climate (e.g., vegetation carbon, total carbon uptake and loss, $\mathrm{MgC}$ ), water quantity (e.g., monthly runoff, $\mathrm{Pg}$ month $^{-1}$ ), water quality (e.g., nitrogen and phosphorus leaching, $\mathrm{PgN} \mathrm{s}^{-1}$ ), soil protection (e.g., erosion protection, 0-100 index), hazards (e.g., costal vulnerability, unitless score; flood risk, number of people affected) and detrimental organisms (e.g., fraction of cropland potentially protected by the natural pest relative to all available cropland, $\mathrm{km}^{2}$ ), and material metrics on bioenergy (e.g., bioenergy-crop production, $\mathrm{PgC}_{r}{ }^{-1}$ ), food and feed (e.g., total crop production, $10^{9} \mathrm{KCal}$ ) and materials (e.g., wood harvest, $\mathrm{KgC}$ ) (Table 6). Some of these metrics require careful interpretation in the context of NCPs (e.g., an increase in flood risk can be caused by climate change and/or by a reduction of the capacity of ecosystems to reduce flood risk) and additional translation of increasing or declining measures of ecosystem functions and services (e.g., food and feed, water quantity) into contextually relevant information (i.e., positive or negative impacts) 
Table 5. Scenario (forcing data) for models in BES-SIM.

\begin{tabular}{|c|c|c|c|c|}
\hline \multirow[b]{2}{*}{$\begin{array}{l}\text { BES-SIM } \\
\text { model }\end{array}$} & \multirow[b]{2}{*}{ Historical } & \multicolumn{3}{|c|}{ Future land-use change or climate (2050) } \\
\hline & & $\begin{array}{c}\text { Land use only, } \\
\text { climate held constant at } 2015 \\
\text { (SSP1, SSP3, SSP5) }\end{array}$ & $\begin{array}{c}\text { Climate change only, } \\
\text { land use held constant at } 2015 \\
\text { (RCP2.6, RCP6.0, RCP8.5) }\end{array}$ & $\begin{array}{c}\text { Land use and climate } \\
\text { (SSP1xRCP2.6, SSP3xRCP6.0, } \\
\text { SSP5xRCP8.5) }\end{array}$ \\
\hline \multicolumn{5}{|c|}{ Species-based models of biodiversity } \\
\hline AIM-biodiversity & $*$ & $*$ & * & * \\
\hline InSiGHTS & $*$ & $*$ & $*$ & $*$ \\
\hline MOL & & & & $*$ \\
\hline \multicolumn{5}{|c|}{ Community-based models of biodiversity } \\
\hline cSAR-iDiv & $*$ & $*$ & & \\
\hline cSAR-IIASA-ETH & $*$ & $*$ & & \\
\hline BILBI & $*$ & $*$ & & $*$ \\
\hline PREDICTS & $*$ & $*$ & & \\
\hline GLOBIO - Aquatic & & & & $*$ \\
\hline GLOBIO - Terrestrial & $*$ & $*$ & $*$ & $*$ \\
\hline \multicolumn{5}{|c|}{ Ecosystems-based model of biodiversity } \\
\hline Madingley & $*$ & & & * \\
\hline \multicolumn{5}{|c|}{ Models of ecosystem functions and services } \\
\hline LPJ-GUESS & $*$ & $*$ & * & * \\
\hline LPJ & $*$ & $*$ & $*$ & $*$ \\
\hline CABLE & $*$ & $*$ & $*$ & $*$ \\
\hline GLOBIO-ES & & & & $*$ \\
\hline InVEST & $*$ & & & $*$ \\
\hline GLOSP & & & & $*$ \\
\hline
\end{tabular}

on human well-being and quality of life. Given the disparity of metrics across models within each NCP category, names of the metrics are listed in Table 6, and units, definitions, and methods are provided in Table S3.

\section{Core simulations}

The simulations for BES-SIM required a minimum of two outputs from the modeling teams: present (2015) and future (2050). Additionally, a past projection (1900) and a further future projection (2070) were also provided by several modeling teams. Some models projected further into the past and also at multiple time points from the past to the future (Appendix A). Models that simulated a continuous time series of climate change impacts provided 20-year averages around these mid-points to account for inter-annual variability. The models ran simulations at their original spatial resolutions (Appendix A), and upscaled results to $1^{\circ}$ grid cells using arithmetic means. In order to provide global or regional averages of the $\alpha$ or grid cell metrics, the arithmetic mean values across the cells of the globe or a certain region were calculated, as well as percentiles of those metrics. Both $1^{\circ}$ rasters and a table with values for each IPBES region and the globe were provided by each modeling team for each output metric.
To measure the individual and synergistic impacts of landuse and climate change on biodiversity and ecosystem services, models accounting for both types of drivers were run three times: with land-use change only, with climate change only, and with both drivers combined. For instance, to measure the impact of land use alone, the projections into 2050 were obtained while retaining climate data constant from the present (2015) to the future (2050). Similarly, to measure the impact of climate change alone, the climate projections into 2050 (or 2070) were obtained while retaining the land-use data constant from the present (2015) to the future (2050). Finally, to measure the impact of land-use and climate change combined, models were run using projections of both land-use and climate change into 2050 (or 2070). When models required continuous climate time-series data to hindcast to 1900 , data from years in the time period 1951 to 1960 were randomly selected to fill the data missing for years 1901 to 1950 from the ISIMIP 2a IPSL dataset. Models that used multi-decadal climate averages from WorldClim (i.e., InSiGHTS, BILBI) assumed no climate impacts for 1900.

\section{Uncertainties}

Reporting uncertainty is a critical component of model intercomparison exercises (IPBES, 2016). Within BES-SIM, un- 


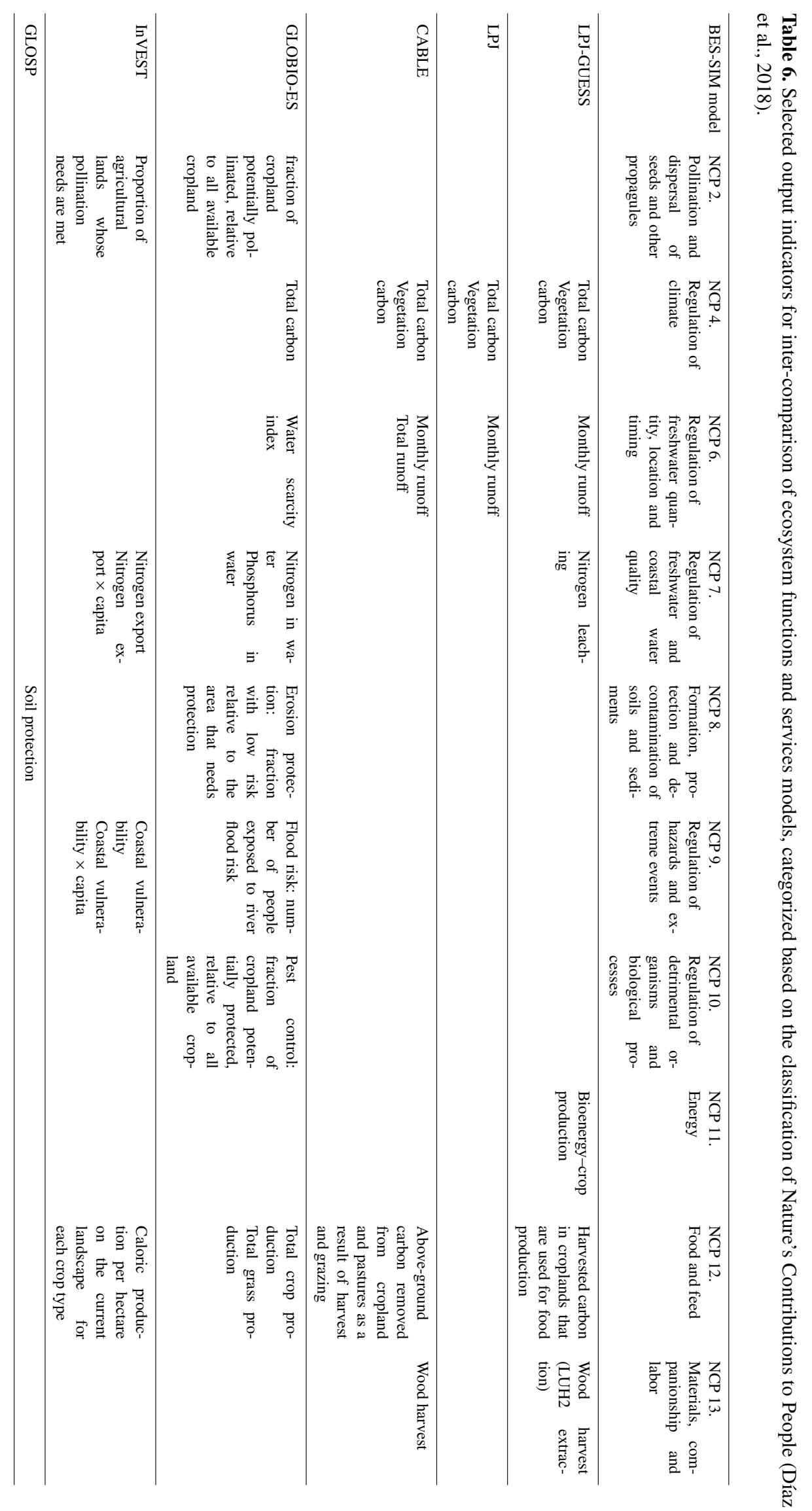


certainties were explored by each model reporting the mean values of its metrics, and where possible the 25th, 50th, and 75th percentiles based on the parameterization set specific to each model, which can be found in each model's key manuscripts describing the modeling methods. When combining the data provided by the different models, the average and the standard deviations of the common metrics were calculated (e.g., intermodel average and standard deviation of $P \gamma$ ). In a parallel exercise to inform BES-SIM, the BIOMOD2 model was used in assessing the uncertainty in modeling changes in species ranges arising from using different RCP scenarios, different GCMs, a suite of species distribution modeling algorithms (e.g., random forest, logistic regression), and different species dispersal hypotheses.

\section{Conclusions}

The existing SSP and RCP scenarios provide a consistent set of past and future projections of two major drivers of terrestrial and freshwater biodiversity change - land use and climate. However, we acknowledge that these projections have certain limitations. These include limited consideration of biodiversity-specific policies in the storylines (only the SSP1 baseline emphasizes additional biodiversity policies) (O'Neill et al., 2016; Rosa et al., 2017), coarse spatial resolution, and land-use classes that are not sufficiently detailed to fully capture the response of biodiversity to land-use change (Harfoot et al., 2014a; Titeux et al., 2016, 2017). The heterogeneity of models and their methodological approaches, as well as additional harmonization of metrics of ecosystem functions and services (Tables 6, S3), are areas for further work. In the future, it will also be important to capture the uncertainties associated with input data, with a focus on uncertainty in land-use and climate projections resulting from differences among IAMs and GCMs on each scenario (Popp et al., 2017). The gaps identified through BES-SIM and future directions for research and modeling will be published separately, as well as analyses of the results on the model intercomparison and on individual models.
As a long-term perspective, BES-SIM is expected to provide critical foundation and insights for the ongoing development of nature-centred, multiscale Nature Futures scenarios (Rosa et al., 2017). Catalyzed by the IPBES Expert Group on Scenarios and Models, this new scenario and modeling framework will shift traditional ways of forecasting impacts of society on nature to more integrative, biodiversity-centred visions and pathways of socio-economic and ecological systems. A future round of BES-SIM could use these biodiversity-centred storylines to project dynamics of biodiversity and ecosystem services and associated consequences for socio-economic development and human well-being. This will help policymakers and practitioners to collectively identify pathways for sustainable futures based on alternative biodiversity management approaches and assist researchers in incorporating the role of biodiversity into socio-economic scenarios.

Code and data availability. The output data from this model intercomparison will be downloadable from the website of the IPBES Expert Group on Scenarios and Models in the future (https: //www.ipbes.net/deliverables/3c-scenarios-and-modelling, last access: 8 November 2018). The LUH2 land-use data used for model runs are available at http://luh.umd.edu/data.shtml (Hurtt et al., 2017). The climate datasets used in BES-SIM can be downloaded from the respective websites (https://www.isimip.org/outputdata/ (Inter-sectoral Impact Model Intercomparison Project Output Data, 2017), http://worldclim.org/version1, Hijmans et al., 2017). 


\section{Appendix A}

Table A1. Description of biodiversity and ecosystem functions and services models in BES-SIM.

\begin{tabular}{|c|c|c|c|c|c|c|c|}
\hline $\begin{array}{l}\text { BES-SIM } \\
\text { model }\end{array}$ & Brief model description & $\begin{array}{l}\text { Defining features and } \\
\text { key processes }\end{array}$ & Model modification & $\begin{array}{l}\text { Spatial } \\
\text { resolu- } \\
\text { tion }\end{array}$ & Time steps & $\begin{array}{l}\text { Taxonomic } \\
\text { or func- } \\
\text { tional } \\
\text { scope }\end{array}$ & $\begin{array}{l}\text { Key } \\
\text { reference }\end{array}$ \\
\hline \multicolumn{8}{|c|}{ Species-based models of biodiversity } \\
\hline $\begin{array}{l}\text { AIM- } \\
\text { biodiversity } \\
\text { (Asia-Pacific } \\
\text { Integrated } \\
\text { Model - biodi- } \\
\text { versity) }\end{array}$ & $\begin{array}{l}\text { A species distribution model } \\
\text { that estimates biodiversity- } \\
\text { loss-based projected shift of } \\
\text { species range under the condi- } \\
\text { tions of land-use and climate } \\
\text { change. }\end{array}$ & $\begin{array}{l}\text { Distribution of suitable habitat } \\
\text { (land) estimated from climate } \\
\text { and land-use data using a statis- } \\
\text { tical model on species presence } \\
\text { and climate and land-use classi- } \\
\text { fications, calibrated by historical } \\
\text { data. }\end{array}$ & $\begin{array}{l}\text { Please see Table S2 for de- } \\
\text { tailed methodology. }\end{array}$ & $0.5^{\circ}$ & $\begin{array}{l}1900,2015 \\
2050,2070\end{array}$ & $\begin{array}{l}\text { Amphibians, } \\
\text { birds, } \\
\text { mammals, } \\
\text { plants, } \\
\text { reptiles }\end{array}$ & $\begin{array}{l}\text { Ohashi et } \\
\text { al. (2018) }\end{array}$ \\
\hline InSiGHTS & $\begin{array}{l}\text { A high-resolution, cell-wise, } \\
\text { species-specific hierarchical } \\
\text { species distribution model } \\
\text { that estimates the extent of } \\
\text { suitable habitat (ESH) for } \\
\text { mammals accounting for land } \\
\text { and climate suitability. }\end{array}$ & $\begin{array}{l}\text { Bioclimatic envelope models fit- } \\
\text { ted based on ecologically current } \\
\text { reference bioclimatic variables. } \\
\text { Species' presence and pseudo- } \\
\text { absence records from sampling } \\
\text { within and outside of species' } \\
\text { ranges. Forecasted layers of land } \\
\text { use/land cover reclassified ac- } \\
\text { cording to expert-based species- } \\
\text { specific suitability indexes. }\end{array}$ & $\begin{array}{l}\text { Increased number of modeled } \\
\text { species and new scenarios for } \\
\text { climate and land use. }\end{array}$ & $0.25^{\circ}$ & $\begin{array}{l}1900,2015 \\
2050,2070\end{array}$ & Mammals & $\begin{array}{l}\text { Rondinini et } \\
\text { al. (2011), } \\
\text { Visconti et } \\
\text { al. (2016) }\end{array}$ \\
\hline $\begin{array}{l}\text { MOL } \\
\text { (Map of Life) }\end{array}$ & $\begin{array}{l}\text { An expert map-based species } \\
\text { distribution model that } \\
\text { projects potential losses in } \\
\text { species occurrences and } \\
\text { geographic range sizes given } \\
\text { changes in suitable conditions } \\
\text { of climate and land-cover } \\
\text { change. }\end{array}$ & $\begin{array}{l}\text { Expert maps for terrestrial am- } \\
\text { phibians, birds and mammals as } \\
\text { a baseline for projections, com- } \\
\text { bined with downscaled layers } \\
\text { for current climate. A penalized } \\
\text { point process model estimated } \\
\text { individual species niche bound- } \\
\text { aries, which were projected into } \\
2050 \text { and } 2070 \text { to estimate range } \\
\text { loss. Species habitat preference- } \\
\text { informed land-cover associations } \\
\text { were used to refine the propor- } \\
\text { tion of suitable habitat in climat- } \\
\text { ically suitable cells with present } \\
\text { and future land-cover-based pro- } \\
\text { jections. }\end{array}$ & $\begin{array}{l}\text { Inductive species distribution } \\
\text { modeling was built using } \\
\text { point process models to delin- } \\
\text { eate niche boundaries. Binary } \\
\text { maps of climatically suitable } \\
\text { cells were rescaled (to [0,1]) } \\
\text { based on the proportion of } \\
\text { the cell within a species } \\
\text { land-cover preference. }\end{array}$ & $0.25^{\circ}$ & $\begin{array}{l}2015,2050 \\
2070\end{array}$ & $\begin{array}{l}\text { Amphibians, } \\
\text { birds, } \\
\text { mammals }\end{array}$ & $\begin{array}{l}\text { Jetz } \quad \text { et } \\
\text { al. (2007), } \\
\begin{array}{l}\text { Merow et } \\
\text { al. }(2013)\end{array}\end{array}$ \\
\hline $\begin{array}{l}\text { BIOMOD2 } \\
\text { (BIOdiversity } \\
\text { MODelling) }\end{array}$ & $\begin{array}{l}\text { An } \mathrm{R} \text { package that allows one } \\
\text { to run up to nine different al- } \\
\text { gorithms of species distribu- } \\
\text { tion models using the same } \\
\text { data and the same framework. } \\
\text { An ensemble could then be } \\
\text { produced allowing a full treat- } \\
\text { ment of uncertainties given } \\
\text { the data, algorithms, climate } \\
\text { models, and climate scenar- } \\
\text { ios. }\end{array}$ & $\begin{array}{l}\text { BIOMOD2 is based on species } \\
\text { distribution models that link } \\
\text { observed or known presence- } \\
\text { absence data to environmental } \\
\text { variables (e.g., climate). Each } \\
\text { model is cross-validated several } \\
\text { times (a random subset of } 70 \% \\
\text { of the data are used for model } \\
\text { calibration, while } 30 \% \text { are held } \\
\text { out for model evaluation). Mod- } \\
\text { els are evaluated using various } \\
\text { metrics. }\end{array}$ & & $100 \mathrm{~km}$ & $\begin{array}{l}2015,2050 \\
2070\end{array}$ & $\begin{array}{l}\text { Amphibians, } \\
\text { birds, } \\
\text { mammals }\end{array}$ & $\begin{array}{l}\text { Thuiller (2004), } \\
\text { Thuiller et } \\
\text { al. (2009, } \\
2011)\end{array}$ \\
\hline \multicolumn{8}{|c|}{ Community-based models of biodiversity } \\
\hline $\begin{array}{l}\text { cSAR (Coun- } \\
\text { tryside Species } \\
\text { Area Relation- } \\
\text { ship) -iDiv }\end{array}$ & $\begin{array}{l}\text { A countryside species- } \\
\text { area relationship model } \\
\text { that estimates the number } \\
\text { of species persisting in a } \\
\text { human-modified landscape, } \\
\text { accounting for the habitat } \\
\text { preferences of different } \\
\text { species groups. }\end{array}$ & $\begin{array}{l}\text { Proportional species richness of } \\
\text { each species group is a power } \\
\text { function of the sum of the areas } \\
\text { of each habitat in a landscape, } \\
\text { weighted by the affinity of each } \\
\text { species group with each habi- } \\
\text { tat type. Species richness is cal- } \\
\text { culated by multiplying the pro- } \\
\text { portional species richness by the } \\
\text { number of species known to oc- } \\
\text { cur in the area. The total number } \\
\text { of species in a landscape is the } \\
\text { sum of the number of species for } \\
\text { each species group. }\end{array}$ & $\begin{array}{l}\text { Two functional groups of } \\
\text { bird species: (1) forest birds; } \\
\text { (2) non-forest birds. Habitat } \\
\text { affinities retrieved from the } \\
\text { PREDICTS database. }\end{array}$ & $0.25^{\circ}$ & $\begin{array}{l}\text { 1900-2010 } \\
\text { (10-year } \\
\text { interval), } \\
2015,2050 \text {, } \\
2070,2090\end{array}$ & $\begin{array}{l}\text { Birds } \\
\text { (forest, } \\
\text { non-forest, } \\
\text { all) }\end{array}$ & $\begin{array}{l}\text { Martins and } \\
\text { Pereira (2017) }\end{array}$ \\
\hline
\end{tabular}


Table A1. Continued.

\begin{tabular}{|c|c|c|c|c|c|c|c|}
\hline $\begin{array}{l}\text { BES-SIM } \\
\text { model }\end{array}$ & Brief model description & $\begin{array}{l}\text { Defining features and } \\
\text { key processes }\end{array}$ & Model modification & $\begin{array}{l}\text { Spatial } \\
\text { resolu- } \\
\text { tion }\end{array}$ & Time steps & $\begin{array}{l}\text { Taxonomic } \\
\text { or func- } \\
\text { tional } \\
\text { scope }\end{array}$ & $\begin{array}{l}\text { Key } \\
\text { reference }\end{array}$ \\
\hline $\begin{array}{l}\text { cSAR-IIASA- } \\
\text { ETH }\end{array}$ & $\begin{array}{l}\text { A countryside species area } \\
\text { relationship model that es- } \\
\text { timates the impact of time } \\
\text { series of spatially explicit } \\
\text { land-use and land-cover } \\
\text { changes on community- } \\
\text { level measures of terrestrial } \\
\text { biodiversity. }\end{array}$ & $\begin{array}{l}\text { Extends concept of the SAR } \\
\text { to mainland environment where } \\
\text { the habitat size depends not } \\
\text { only on the extent of the orig- } \\
\text { inal pristine habitat, but also } \\
\text { on the extent and taxon-specific } \\
\text { affinity of the other non-pristine } \\
\text { land uses and land covers } \\
\text { (LULC) of conversion. Affini- } \\
\text { ties derived from field records. } \\
\text { Produces the average habi- } \\
\text { tat suitability, regional species } \\
\text { richness, and loss of threatened } \\
\text { and endemic species for five } \\
\text { taxonomic groups. }\end{array}$ & $\begin{array}{l}\text { Refined link between } \\
\text { LULCC and habitat (gross } \\
\text { transitions between LULC } \\
\text { classes at each time) and } \\
\text { better accounting of time } \\
\text { dynamics of converted } \\
\text { LULC classes. }\end{array}$ & $0.25^{\circ}$ & $\begin{array}{l}\text { 1500-1900 } \\
\text { (100-year } \\
\text { interval), } \\
1900-2090 \\
\text { (10-year } \\
\text { interval) }\end{array}$ & $\begin{array}{l}\text { Amphibians, } \\
\text { birds, } \\
\text { mammals, } \\
\text { plants, } \\
\text { reptiles }\end{array}$ & $\begin{array}{l}\text { Chaudhary } \\
\text { et } \\
\text { al. (2015), } \\
\text { UNEP (2016) }\end{array}$ \\
\hline $\begin{array}{l}\text { BILBI (Bio- } \\
\text { geographic } \\
\text { modelling } \\
\text { Infrastructure } \\
\text { for Large-scale } \\
\text { Biodiversity } \\
\text { Indicators) }\end{array}$ & $\begin{array}{l}\text { A modeling framework that } \\
\text { couples application of the } \\
\text { species-area relationship } \\
\text { with correlative generalized } \\
\text { dissimilarity modeling } \\
\text { (GDM)-based modeling of } \\
\text { continuous patterns of spa- } \\
\text { tial and temporal turnover } \\
\text { in the species composition } \\
\text { of communities (applied in } \\
\text { this study to vascular plant } \\
\text { species globally). }\end{array}$ & $\begin{array}{l}\text { The potential effects of climate } \\
\text { scenarios on beta-diversity } \\
\text { patterns are estimated through } \\
\text { space-for-time projection of } \\
\text { compositional-turnover models } \\
\text { fitted to present-day biolog- } \\
\text { ical and environmental data. } \\
\text { These projections are then } \\
\text { combined with downscaled } \\
\text { land-use scenarios to estimate } \\
\text { the proportion of species ex- } \\
\text { pected to persist within any } \\
\text { given region. This employs } \\
\text { an extension of species-area } \\
\text { modeling designed to work } \\
\text { with biologically scaled envi- } \\
\text { ronments varying continuously } \\
\text { across space and time. }\end{array}$ & $\begin{array}{l}\text { Please see Table } \mathrm{S} 3 \text { for de- } \\
\text { tailed methodology. }\end{array}$ & $\begin{array}{l}1 \mathrm{~km} \\
(30 \text { arc- } \\
\mathrm{sec})\end{array}$ & $\begin{array}{l}1900,2015, \\
2050\end{array}$ & $\begin{array}{l}\text { Vascular } \\
\text { plants }\end{array}$ & $\begin{array}{l}\text { Ferrier et } \\
\text { al. (2004, } \\
2007)\end{array}$ \\
\hline $\begin{array}{l}\text { PREDICTS } \\
\text { (Projecting } \\
\text { Responses } \\
\text { of Ecologi- } \\
\text { cal Diversity } \\
\text { In Changing } \\
\text { Terrestrial } \\
\text { Systems) }\end{array}$ & $\begin{array}{l}\text { The hierarchical mixed- } \\
\text { effects model that estimates } \\
\text { how four measures of site- } \\
\text { level terrestrial biodiversity } \\
\text { - overall abundance, } \\
\text { within-sample species } \\
\text { richness, abundance-based } \\
\text { compositional similarity } \\
\text { and richness-based com- } \\
\text { positional similarity - } \\
\text { respond to land use and } \\
\text { related pressures. }\end{array}$ & $\begin{array}{l}\text { Models employ data from } \\
\text { the PREDICTS database en- } \\
\text { compassing } 767 \text { studies from } \\
\text { over } 32000 \text { sites on over } \\
51000 \text { species. Models assess } \\
\text { how alpha diversity is affected } \\
\text { by land use, land-use intensity, } \\
\text { and human population density. } \\
\text { Model coefficients are com- } \\
\text { bined with past, present and } \\
\text { future maps of the pressure } \\
\text { data to make global projections } \\
\text { of response variables, which } \\
\text { are combined to yield the } \\
\text { variants of the Biodiversity } \\
\text { Intactness Index (an indicator } \\
\text { first proposed by Scholes and } \\
\text { Biggs, 2005). }\end{array}$ & $\begin{array}{l}\text { PREDICTS LU classes } \\
\text { recurated for LUH2. Abun- } \\
\text { dance rescaled within } \\
\text { each study. Baseline of } \\
\text { minimally used primary } \\
\text { vegetation. Compositional } \\
\text { similarity models in- } \\
\text { cluded human population. } \\
\text { Study-level mean human } \\
\text { population and agricultural } \\
\text { suitability used as control } \\
\text { variables. Proximity to road } \\
\text { omitted. }\end{array}$ & $0.25^{\circ}$ & $900-2100$ & All & $\begin{array}{l}\text { Newbold et } \\
\text { al. (2016), } \\
\text { Purvis et } \\
\text { al. (2018) }\end{array}$ \\
\hline $\begin{array}{l}\text { GLOBIO } \\
\text { (GLObal BIO- } \\
\text { diversity) - } \\
\text { Aquatic }\end{array}$ & $\begin{array}{l}\text { A modeling framework } \\
\text { that quantifies the impacts } \\
\text { of land use, eutrophica- } \\
\text { tion, climate change, and } \\
\text { hydrological disturbance } \\
\text { on freshwater biodiver- } \\
\text { sity, quantified as the } \\
\text { mean species abundance } \\
\text { (MSA) and ecosystem } \\
\text { functions/services. }\end{array}$ & $\begin{array}{l}\text { Comprises a set of (mostly cor- } \\
\text { relative) relationships between } \\
\text { anthropogenic drivers and bio- } \\
\text { diversity/ES of rivers, lakes and } \\
\text { wetlands. Based on the catch- } \\
\text { ment approach; i.e., the pres- } \\
\text { sures on the aquatic ecosystems } \\
\text { are based on what happens in } \\
\text { their catchment. Based on the } \\
\text { literature. }\end{array}$ & & $0.5^{\circ}$ & 2015,2050 & All & $\begin{array}{l}\text { Janse et } \\
\text { al. (2015, } \\
2016)\end{array}$ \\
\hline
\end{tabular}


Table A1. Continued.

\begin{tabular}{|c|c|c|c|c|c|c|c|}
\hline $\begin{array}{l}\text { BES-SIM } \\
\text { model }\end{array}$ & Brief model description & $\begin{array}{l}\text { Defining features and } \\
\text { key processes }\end{array}$ & Model modification & $\begin{array}{l}\text { Spatial } \\
\text { resolu- } \\
\text { tion }\end{array}$ & Time steps & $\begin{array}{l}\text { Taxonomic } \\
\text { or func- } \\
\text { tional } \\
\text { scope }\end{array}$ & $\begin{array}{l}\text { Key } \\
\text { reference }\end{array}$ \\
\hline $\begin{array}{l}\text { GLOBIO - } \\
\text { Terrestrial }\end{array}$ & $\begin{array}{l}\text { A modeling framework } \\
\text { that quantifies the impacts } \\
\text { of multiple anthropogenic } \\
\text { pressures on local biodiver- } \\
\text { sity (MSA). }\end{array}$ & $\begin{array}{l}\text { Based on a set of correlative } \\
\text { relationships between biodiver- } \\
\text { sity (MSA) on the one hand and } \\
\text { anthropogenic pressures on the } \\
\text { other, quantified based on meta- } \\
\text { analyses of biodiversity data re- } \\
\text { ported in the literature. Geo- } \\
\text { referenced layers of the pres- } \\
\text { sure variables are then com- } \\
\text { bined with the response rela- } \\
\text { tionships to quantify changes in } \\
\text { biodiversity. }\end{array}$ & $\begin{array}{l}\text { Improved land-use alloca- } \\
\text { tion routine, improved re- } \\
\text { sponse relationships for en- } \\
\text { croachment (hunting) }\end{array}$ & $\begin{array}{l}10 \text { arc- } \\
\operatorname{sec~} \quad(\sim \\
300 \mathrm{~m})\end{array}$ & 2015,2050 & All & $\begin{array}{l}\text { Schipper et } \\
\text { al. (2016) }\end{array}$ \\
\hline \multicolumn{8}{|c|}{ Ecosystems-based model of biodiversity } \\
\hline Madingley & $\begin{array}{l}\text { An integrated process- } \\
\text { based, mechanistic, general } \\
\text { ecosystem model that uses } \\
\text { a unified set of fundamental } \\
\text { ecological concepts and } \\
\text { processes to predict the } \\
\text { structure and function of } \\
\text { the ecosystems at various } \\
\text { levels of organization for } \\
\text { marine or terrestrial. }\end{array}$ & $\begin{array}{l}\text { Grouped by heterotroph co- } \\
\text { horts, organisms are defined } \\
\text { by functional traits rather than } \\
\text { the taxonomy. Heterotrophs, } \\
\text { defined by categorical (trophic } \\
\text { group; thermoregulation strat- } \\
\text { egy; reproductive strategy) } \\
\text { and quantitative (current body } \\
\text { mass; mass at birth; and mass } \\
\text { at reproductive maturity) traits, } \\
\text { are modeled as individuals } \\
\text { dynamically. Simulates the } \\
\text { autotroph ecological processes } \\
\text { of growth and mortality; and } \\
\text { heterotroph metabolism, eating, } \\
\text { reproduction, growth, mortal- } \\
\text { ity, and dispersal. Dispersal is } \\
\text { determined by the body mass. }\end{array}$ & $\begin{array}{l}\text { Incorporation of temporally } \\
\text { changing climate, and nat- } \\
\text { ural and human-impacted } \\
\text { plant stocks, to better rep- } \\
\text { resent the LUHv2 land-use } \\
\text { projections. Calculation of } \\
\text { functional diversity and dis- } \\
\text { similarity to represent com- } \\
\text { munity changes }\end{array}$ & $1^{\circ}$ & $\begin{array}{l}1901, \\
1915-2070 \\
\text { (5-year } \\
\text { interval) }\end{array}$ & $\begin{array}{l}\text { Three } \\
\text { functional } \\
\text { groups }\end{array}$ & $\begin{array}{l}\text { Harfoot et } \\
\text { al. }(2014 b)\end{array}$ \\
\hline \multicolumn{8}{|c|}{ Models of ecosystem functions and services } \\
\hline $\begin{array}{l}\text { LPJ-GUESS } \\
\text { (Lund- } \\
\text { Potsdam- } \\
\text { Jena General } \\
\text { Ecosystem } \\
\text { Simulator) }\end{array}$ & $\begin{array}{l}\text { A process-based "demog- } \\
\text { raphy enabled" dynamic } \\
\text { global vegetation model } \\
\text { that computes vegetation } \\
\text { and soil state and function, } \\
\text { as well as distribution of } \\
\text { vegetation units dynam- } \\
\text { ically in space and time } \\
\text { in response to climate } \\
\text { change, land-use change } \\
\text { and } N \text {-input. }\end{array}$ & $\begin{array}{l}\text { Vegetation dynamics result } \\
\text { from growth and competition } \\
\text { for light, space, and soil re- } \\
\text { sources among woody plant } \\
\text { individuals and herbaceous un- } \\
\text { derstorey. A suite of simulated } \\
\text { patches per grid cell represents } \\
\text { stochastic processes of growth } \\
\text { and mortality (succession), } \\
\text { Individuals for woody PFTs } \\
\text { are identical within an age } \\
\text { cohort. Processes such as } \\
\text { photosynthesis, respiration, } \\
\text { and stomatal conductance are } \\
\text { simulated daily. Net primary } \\
\text { production (NPP) accrued at } \\
\text { the end of each simulation year } \\
\text { is allocated to leaves, fine roots, } \\
\text { and, for woody PFTs, sapwood, } \\
\text { resulting in height, diameter } \\
\text { and biomass growth. }\end{array}$ & $\begin{array}{l}\text { The model version used } \\
\text { here has some updates to } \\
\text { the fire model compared } \\
\text { to Knorr et al. (2016); see } \\
\text { also Rabin et al. (2017). } \\
\text { Simulations also accounted } \\
\text { for wood harvest, using the } \\
\text { modeled recommendations } \\
\text { from LUH2. }\end{array}$ & $0.5^{\circ}$ & $\begin{array}{l}1920,1950, \\
1970,2015, \\
2050,2070\end{array}$ & & $\begin{array}{l}\text { Lindeskog } \\
\text { et } \\
\text { al. (2013), } \\
\text { Olin et } \\
\text { al. (2015), } \\
\text { Smith et } \\
\text { al. (2014) }\end{array}$ \\
\hline
\end{tabular}


Table A1. Continued.

\begin{tabular}{|c|c|c|c|c|c|c|c|}
\hline $\begin{array}{l}\text { BES-SIM } \\
\text { model }\end{array}$ & Brief model description & $\begin{array}{l}\text { Defining features and } \\
\text { key processes }\end{array}$ & Model modification & $\begin{array}{l}\text { Spatial } \\
\text { resolu- } \\
\text { tion }\end{array}$ & Time steps & $\begin{array}{l}\text { Taxonomic } \\
\text { or func- } \\
\text { tional } \\
\text { scope }\end{array}$ & $\begin{array}{l}\text { Key } \\
\text { reference }\end{array}$ \\
\hline $\begin{array}{l}\text { LPJ } \\
\text { (Lund- } \\
\text { Potsdam-Jena) }\end{array}$ & $\begin{array}{l}\text { A big leaf model that sim- } \\
\text { ulates the coupled dynam- } \\
\text { ics of biogeography, bio- } \\
\text { geochemistry and hydrol- } \\
\text { ogy under varying climate, } \\
\text { atmospheric } \mathrm{CO}_{2} \text { concen- } \\
\text { trations, and land-use land- } \\
\text { cover change practices to } \\
\text { represent demography of } \\
\text { grasses and trees in a scale } \\
\text { from individuals to land- } \\
\text { scapes. }\end{array}$ & $\begin{array}{l}\text { Hierarchical representation of } \\
\text { the land surface - tiles repre- } \\
\text { sent land use with various plant } \\
\text { or crop functional types. Im- } \\
\text { plements establishment, mor- } \\
\text { tality, fire, carbon allocation, } \\
\text { and land-cover change on an- } \\
\text { nual time steps, and calculates } \\
\text { photosynthesis, autotrophic res- } \\
\text { piration, and heterotrophic res- } \\
\text { piration on daily time steps. } \\
\text { Fully prognostic, meaning that } \\
\text { PFT distributions and phenol- } \\
\text { ogy are simulated based on } \\
\text { physical principles within a nu- } \\
\text { merical framework. }\end{array}$ & $\begin{array}{l}\text { LPJ represents the full set } \\
\text { of states and transitions } \\
\text { represented in LUHv } 2 \text { and } \\
\text { improved estimate of car- } \\
\text { bon fluxes from land-cover } \\
\text { change. }\end{array}$ & $0.5^{\circ}$ & $\begin{array}{l}1920,1950, \\
1970,2015, \\
2050,2070\end{array}$ & & $\begin{array}{l}\text { Poulter et } \\
\text { al. (2011), } \\
\text { Sitch et } \\
\text { al. (2003) }\end{array}$ \\
\hline $\begin{array}{l}\text { CABLE } \\
\text { (Community } \\
\text { Atmosphere } \\
\text { Biosphere Land } \\
\text { Exchange) }\end{array}$ & $\begin{array}{l}\text { A "demography enabled" } \\
\text { global terrestrial biosphere } \\
\text { model that computes veg- } \\
\text { etation and soil state and } \\
\text { function dynamically in } \\
\text { space and time in response } \\
\text { to climate change, land-use } \\
\text { change and } N \text {-input. }\end{array}$ & $\begin{array}{l}\text { Combines biophysics (coupled } \\
\text { photosynthesis, stomatal con- } \\
\text { ductance, canopy energy bal- } \\
\text { ance) with daily biogeochemi- } \\
\text { cal cycling of carbon and nitro- } \\
\text { gen (CASA-CNP) and annual } \\
\text { patch-based representation of } \\
\text { vegetation structural dynamics } \\
\text { (POP). Accounts for gross land- } \\
\text { use transitions and wood har- } \\
\text { vest, including effects on patch } \\
\text { age distribution in secondary } \\
\text { forest. } \\
\text { Simulates co-ordination of rate- } \\
\text { limiting processes in } \mathrm{C}_{3} \text { photo- } \\
\text { synthesis, as an outcome of fit- } \\
\text { ness maximization. }\end{array}$ & & $1^{\circ}$ & $\begin{array}{l}1920,1950, \\
1970,2015, \\
2050,2070\end{array}$ & & $\begin{array}{l}\text { Haverd et } \\
\text { al. (2018) }\end{array}$ \\
\hline $\begin{array}{l}\text { GLOBIO - } \\
\text { Ecosystem } \\
\text { Services }\end{array}$ & $\begin{array}{l}\text { The model simulates the in- } \\
\text { fluence of various anthro- } \\
\text { pogenic drivers on ecosys- } \\
\text { tem functions and services. }\end{array}$ & $\begin{array}{l}\text { Quantifies a range of provi- } \\
\text { sioning services (e.g., crop pro- } \\
\text { duction, grass and fodder pro- } \\
\text { duction, wild food), regulat- } \\
\text { ing services (e.g., pest control, } \\
\text { pollination, erosion risk reduc- } \\
\text { tion, carbon sequestration), and } \\
\text { culture services (e.g., nature- } \\
\text { based tourism) and other mea- } \\
\text { sures (e.g., water availability, } \\
\text { food risk reduction, harmful } \\
\text { algal blooms). Derived from } \\
\text { various models, including the } \\
\text { Integrated Model to Assess } \\
\text { the Global Environment (IM- } \\
\text { AGE) model and PCRaster } \\
\text { Global Water Balance (PCR- } \\
\text { GLOBWB), and from empiri- } \\
\text { cal studies using meta-analysis. }\end{array}$ & $\begin{array}{l}\text { Relationships between land } \\
\text { use and the presence of } \\
\text { pollinators and predators } \\
\text { updated through additional } \\
\text { peer review papers. }\end{array}$ & $0.5^{\circ}$ & $\begin{array}{l}2015,2050, \\
2070\end{array}$ & & $\begin{array}{l}\text { Alkemade } \\
\text { et al. (2009, } \\
2014), \\
\text { Schulp et } \\
\text { al. (2012) }\end{array}$ \\
\hline
\end{tabular}


Table A1. Continued.

\begin{tabular}{|c|c|c|c|c|c|c|c|}
\hline $\begin{array}{l}\text { BES-SIM } \\
\text { model }\end{array}$ & Brief model description & $\begin{array}{l}\text { Defining features and } \\
\text { key processes }\end{array}$ & Model modification & $\begin{array}{l}\text { Spatial } \\
\text { resolu- } \\
\text { tion }\end{array}$ & Time steps & $\begin{array}{l}\text { Taxonomic } \\
\text { or func- } \\
\text { tional } \\
\text { scope }\end{array}$ & $\begin{array}{l}\text { Key } \\
\text { reference }\end{array}$ \\
\hline $\begin{array}{l}\text { InVEST } \\
\text { (Integrated } \\
\text { Valuation of } \\
\text { Ecosystem } \\
\text { Services and } \\
\text { Tradeoffs) }\end{array}$ & $\begin{array}{l}\text { A suite of geographic infor- } \\
\text { mation system (GIS) based } \\
\text { spatially explicit models } \\
\text { used to map and value the } \\
\text { ecosystem goods and ser- } \\
\text { vices in biophysical or eco- } \\
\text { nomic terms. }\end{array}$ & $\begin{array}{l}18 \text { models for distinct ecosys- } \\
\text { tem services designed for ter- } \\
\text { restrial, freshwater, marine and } \\
\text { coastal ecosystems. Based on } \\
\text { production functions that define } \\
\text { how changes in an ecosystem's } \\
\text { structure and function are likely } \\
\text { to affect the flows and values } \\
\text { of ecosystem services across a } \\
\text { landscape or a seascape. Ac- } \\
\text { counts for both service supply } \\
\text { and the location and activities } \\
\text { of demand. Modular and se- } \\
\text { lectable. }\end{array}$ & $\begin{array}{l}\text { The crop-production } \\
\text { model was simplified from } \\
175 \text { crops to the } 5 \text { crop } \\
\text { types reported in LUH2. } \\
\text { Other models have minor } \\
\text { simplifications; see Ta- } \\
\text { bles S2 and S3 for more } \\
\text { detail. }\end{array}$ & $\begin{array}{l}300 \mathrm{~m} \\
\text { and } \\
5 \quad \text { ar- } \\
\text { cmin }\end{array}$ & 2015,2050 & & $\begin{array}{l}\text { Arkema et } \\
\text { al. (2013), } \\
\text { Chaplin- } \\
\text { Kramer et } \\
\text { al. (2014), } \\
\text { Guannel et } \\
\text { al. (2016), } \\
\text { Johnson et } \\
\text { al. (2014, } \\
\text { 2016), } \\
\text { Redhead et } \\
\text { al. (2018), } \\
\text { Sharp et } \\
\text { al. (2016) }\end{array}$ \\
\hline $\begin{array}{l}\text { GLOSP } \\
\text { (GLObal } \\
\text { Soil Protection) }\end{array}$ & $\begin{array}{l}\text { A 2-D soil erosion model } \\
\text { based on the Universal Soil } \\
\text { Loss Equation that uses cli- } \\
\text { mate and land-use projec- } \\
\text { tions to estimate global and } \\
\text { local soil protection. }\end{array}$ & $\begin{array}{l}\text { Protected soil (Ps) is defined as } \\
\text { the amount of soil that is pre- } \\
\text { vented from being eroded (wa- } \\
\text { ter erosion) by the mitigating } \\
\text { effect of available vegetation. } \\
\text { Ps is calculated from the differ- } \\
\text { ence between soil erosion (Se) } \\
\text { and potential soil erosion (Pse) } \\
\text { based on the integration of the } \\
\text { joint effect of slope length, rain- } \\
\text { fall erosivity, and soil erodibil- } \\
\text { ity. Soil protection is given by } \\
\text { the value of fractional vegeta- } \\
\text { tion cover calculated as a func- } \\
\text { tion of land use, altitude, pre- } \\
\text { cipitation, and soil properties. }\end{array}$ & $\begin{array}{l}\text { Please see Table S3 for de- } \\
\text { tailed methodology. }\end{array}$ & $0.25^{\circ}$ & 2015,2050 & & $\begin{array}{l}\text { Guerra et } \\
\text { al. }(2016)\end{array}$ \\
\hline
\end{tabular}


Appendix B: List of acronyms

$\begin{array}{ll}\text { AIM } & \text { Asia-pacific Integrated Model } \\ \text { BES-SIM } & \text { Biodiversity and Ecosystem Services Scenario-based Intercomparison of Models } \\ \text { BIOMOD } & \text { BIOdiversity MODelling } \\ \text { BILBI } & \text { Biogeographic modelling Infrastructure for Large-scale Biodiversity Indicators } \\ \text { CABLE } & \text { Community Atmosphere Biosphere Land Exchange } \\ \text { CMIP } & \text { Climate Model Inter-comparison Project } \\ \text { cSAR } & \text { Countryside Species Area Relationship } \\ \text { DGVM } & \text { Dynamic global vegetation model } \\ \text { EBV } & \text { Essential biodiversity variable } \\ \text { ESMs } & \text { Earth system models } \\ \text { GBIF } & \text { Global Biodiversity Information Facility } \\ \text { GBO } & \text { Global Biodiversity Outlooks } \\ \text { GCMs } & \text { General circulation models } \\ \text { GEO } & \text { Global Environmental Outlook } \\ \text { GLOBIO } & \text { GLObal BIOdiversity } \\ \text { GLOSP } & \text { GLObal Soil Protection } \\ \text { IAM } & \text { Integrated Assessment Models } \\ \text { IMAGE } & \text { Integrated Model to Assess the Global Environment } \\ \text { InVEST } & \text { Integrated Valuation of Ecosystem Services and Tradeoffs } \\ \text { IPBES } & \text { Intergovernmental Science-Policy Platform on Biodiversity and Ecosystem Services } \\ \text { IPCC } & \text { Intergovernmental Panel on Climate Change } \\ \text { IPSL-CM5A-LR } & \text { Institut Pierre-Simon Laplace-Climate Model 5A-Low Resolution } \\ \text { ISI-MIP } & \text { Inter-Sectoral Impact Model Intercomparison Project } \\ \text { LPJ } & \text { Lund-Potsdam-Jena } \\ \text { LPJ-GUESS } & \text { Lund-Potsdam-Jena General Ecosystem Simulator } \\ \text { LUH2 } & \text { Land Use Harmonization Project version 2 } \\ \text { MA } & \text { Millennium Ecosystem Assessment } \\ \text { MAgPIE } & \text { The Model of Agricultural Production and its Impact on the Environment } \\ \text { MIP } & \text { Model Intercomparison Project } \\ \text { MOL } & \text { Map of Life } \\ \text { NCP } & \text { Nature's Contributions to People } \\ \text { REMIND } & \text { Regionalized Model of Investments and Development } \\ \text { PREDICTS } & \text { Projecting Responses of Ecological Diversity In Changing Terrestrial Systems } \\ \text { RCM } & \text { Regional Climate Models } \\ \text { RCPs } & \text { Representative Concentration Pathways } \\ \text { PCR-GLOBWB } & \text { PCRaster Global Water Balance } \\ \text { SAR } & \text { Species-area relationship } \\ \text { SR } & \text { Species richness } \\ \text { SSPs } & \text { Shared Socio-economic Pathways } \\ & \end{array}$


Supplement. The supplement related to this article is available online at: https://doi.org/10.5194/gmd-11-4537-2018-supplement.

Author contributions. All the authors co-designed the study and provided scientific input and technical details on models, scenarios and data necessary to carry out the intermodel comparison and synthesis. HMP, RA, PL, and IMDR led the development of the protocol, and HK led the writing of the manuscript with model-specific text contributions and review comments from all co-authors.

Competing interests. The authors declare that they have no conflict of interest.

Acknowledgements. HyeJin Kim, Inês Santos Martins, Florian Wolf, Carlos Guerra, and Henrique M. Pereira are supported by the German Centre for Integrative Biodiversity Research (iDiv) HalleJena-Leipzig, funded by the German Research Foundation (FZT 118). Isabel Maria Duarte Rosa acknowledges funding from the European Union's Horizon 2020 research and innovation program under Marie Sklodowska-Curie grant agreement no. 703862. Paul Leadley is supported by the LabEx BASC supported by the French "Investment d'Avenir" program (grant ANR-11-LABX-0034). George C. Hurtt and Louise Parsons Chini gratefully acknowledge the support of the DOE-SciDAC program (DE SC0012972). Almut Arneth, Andreas Krause, Benjamin Quesada, and Peter Anthoni acknowledge support from the Helmholtz Association and its ATMO Programme, and EU FP7 project LUC4C. Andy Purvis, Adriana De Palm, and Samantha L. L. Hill are supported by the Natural Environment Research Council U.K. (grant number NE/M014533/1) and by a DIF grant from the Natural History Museum. Rebecca Chaplin-Kramer and Richard Sharp are supported by private gifts to the Natural Capital Project. David Leclère, Fulvio Di Fulvio, Petr Havlík, and Michael Obersteiner are supported by the project IS-WEL-Integrated Solutions for Water, Energy and Land funding from the Global Environmental Facility, Washington, USA, coordinated by the United Nations Industrial Development Organization (UNIDO), UNIDO project no. 140312. Fulvio Di Fulvio and Michael Obersteiner are supported by the ERC SYNERGY grant project IMBALANCE-P-Managing Phosphorous limitation in a nitrogen-saturated Anthropocene, funding from the European Commission, European Research Council Executive Agency, grant agreement no. 610028. David Leclère and Petr Havlík are supported by project SIGMA Stimulating Innovation for Global Monitoring of Agriculture - and its Impact on the Environment in support of GEOGLAM, funding from the European Union's FP7 research and innovation program under the environment area, grant agreement no. 603719. Tomoko Hasegawa, Haruka Ohashi, Akiko Hirata, Shinichiro Fujimori, Tetsuya Matsui, and Kiyoshi Takahashi are supported by the Global Environmental Research (S-14) of the Ministry of the Environment of Japan. Tomoko Hasegawa, Shinichiro Fujimori, and Kiyoshi Takahashi are supported by Environment Research and Technology Development Fund 2-1702 of the Environmental Restoration and Conservation Agency of Japan. Mike Harfoot is supported by a KR Rasmussen Foundation grant "Modelling the Biodiversity Planetary Boundary and Embedding Results into Policy" (FP-
1503-01714). Vanessa Haverd acknowledges support from the Earth Systems and Climate Change Hub, funded by the Australian Government's National Environmental Science program. Cory Merow acknowledges funding from NSF grant DEB1565046. Finally, we also thank the following organizations for funding the workshops: the PBL Netherland Environment Assessment Agency, UNESCO (March 2016), the iDiv German Centre for Integrative Biodiversity Research (October 2016, October 2017), and the Zoological Society of London (January 2018).

Edited by: Hisashi Sato

Reviewed by: two anonymous referees

\section{References}

Aguirre-Gutiérrez, J., Carvalheiro, L. G., Polce, C., van Loon, E. E., Raes, N., Reemer, M., Biesmeijer, J. C., and Chapman, M. G. (Eds.): Fit-for-Purpose: Species Distribution Model Performance Depends on Evaluation Criteria Dutch Hoverflies as a Case Study, PLoS ONE, 8, e63708, https://doi.org/10.1371/journal.pone.0063708, 2013.

Akçakaya, H. R., Pereira, H. M., Canziani, G. A., Mbow, C., Mori, A., Palomo, M. G., Soberoin, J., Thuiller, W., Yachi, S., Ferrier, S., Ninan, K. N., Leadley, P., Alkemade, R., Acosta, L. A., Akçakaya, H. R., Brotons, L., Cheung, W. W. L., Christensen, V., Harhash, K. A., Kabubo-Mariara, J., Lundquist, C., Obersteiner, M., Pereira, H. M., Peterson, G., Pichs-Madruga, R., Ravindranath, N., Rondinini, C., and Wintle, B. A. (Eds.): Improving the rigour and usefulness of scenarios and models through ongoing evaluation and refinement, The methodological assessment report on scenarios and models of biodiversity and ecosystem services, Secretariat of the Intergovernmental Science-Policy Platform for Biodiversity and Ecosystem Services, Bonn, Germany, 2015.

Alkemade, R., van Oorschot, M., Miles, L., Nellemann, C., Bakkenes, M., and ten Brink, B.: GLOBIO3: A Framework to Investigate Options for Reducing Global Terrestrial Biodiversity Loss, Ecosystems, 12, 374-390, https://doi.org/10.1007/s10021009-9229-5, 2009.

Alkemade, R., Burkhard, B., Crossman, N. D., Nedkov, S., and Petz, K.: Quantifying ecosystem services and indicators for science, policy and practice, Ecol. Indic., 37, 161-162, https://doi.org/10.1016/j.ecolind.2013.11.014, 2014.

Arkema, K. K., Guannel, G., Verutes, G., Wood, S. A., Guerry, A., Ruckelshaus, M., Kareiva, P., Lacayo, M., and Silver, J. M.: Coastal habitats shield people and property from sea-level rise and storms, Nat. Clim. Change, 3, 913-918, https://doi.org/10.1038/nclimate1944, 2013.

Arneth, A., Sitch, S., Pongratz, J., Stocker, B. D., Ciais, P., Poulter, B., Bayer, A. D., Bondeau, A., Calle, L., Chini, L. P., Gasser, T., Fader, M., Friedlingstein, P., Kato, E., Li, W., Lindeskog, M., Nabel, J. E. M. S., Pugh, T. A. M., Robertson, E., Viovy, N., Yue, C., and Zaehle, S.: Historical carbon dioxide emissions caused by land-use changes are possibly larger than assumed, Nat. Geosci., 10, 79-84, https://doi.org/10.1038/ngeo2882, 2017.

Bellard, C., Bertelsmeier, C., Leadley, P., Thuiller, W., and Courchamp, F.: Impacts of climate change on the future of biodiver- 
sity: Biodiversity and climate change, Ecol. Lett., 15, 365-377, https://doi.org/10.1111/j.1461-0248.2011.01736.x, 2012.

Beusen, A. H. W., Van Beek, L. P. H., Bouwman, A. F., Mogollón, J. M., and Middelburg, J. J.: Coupling global models for hydrology and nutrient loading to simulate nitrogen and phosphorus retention in surface water - description of IMAGE-GNM and analysis of performance, Geosci. Model Dev., 8, 4045-4067, https://doi.org/10.5194/gmd-8-4045-2015, 2015.

Brooks, T. M., Akçakaya, H. R., Burgess, N. D., Butchart, S. H. M., Hilton-Taylor, C., Hoffmann, M., Juffe-Bignoli, D., Kingston, N., MacSharry, B., Parr, M., Perianin, L., Regan, E. C., Rodrigues, A. S. L., Rondinini, C., Shennan-Farpon, Y., and Young, B. E.: Analysing biodiversity and conservation knowledge products to support regional environmental assessments, Scientific Data, 3, 160007, https://doi.org/10.1038/sdata.2016.7, 2016.

Cardinale, B. J., Duffy, J. E., Gonzalez, A., Hooper, D. U., Perrings, C., Venail, P., Narwani, A., Mace, G. M., Tilman, D., Wardle, D. A., Kinzig, A. P., Daily, G. C., Loreau, M., Grace, J. B., Larigauderie, A., Srivastava, D. S., and Naeem, S.: Biodiversity loss and its impact on humanity, Nature, 486, 59-67, https://doi.org/10.1038/nature11148, 2012.

Chaplin-Kramer, R., Dombeck, E., Gerber, J., Knuth, K. A., Mueller, N. D., Mueller, M., Ziv, G., and Klein, A.-M.: Global malnutrition overlaps with pollinator-dependent micronutrient production, P. R. Soc. B-Biol. Sci., 281, 20141799-20141799, https://doi.org/10.1098/rspb.2014.1799, 2014.

Chaudhary, A., Verones, F., de Baan, L., and Hellweg, S.: Quantifying Land Use Impacts on Biodiversity: Combining Species-Area Models and Vulnerability Indicators, Environ. Sci. Technol., 49, 9987-9995, https://doi.org/10.1021/acs.est.5b02507, 2015.

D'Amen, M., Rahbek, C., Zimmermann, N. E., and Guisan, A.: Spatial predictions at the community level: from current approaches to future frameworks: Methods for community-level spatial predictions, Biol. Rev., 92, 169-187, https://doi.org/10.1111/brv.12222, 2017.

Díaz, S., Pascual, U., Stenseke, M., Martín-López, B., Watson, R. T., Molnár, Z., Hill, R., Chan, K. M. A., Baste, I. A., Brauman, K. A., Polasky, S., Church, A., Lonsdale, M., Larigauderie, A., Leadley, P. W., van Oudenhoven, A. P. E., van der Plaat, F., Schröter, M., Lavorel, S., Aumeeruddy-Thomas, Y., Bukvareva, E., Davies, K., Demissew, S., Erpul, G., Failler, P., Guerra, C. A., Hewitt, C. L., Keune, H., Lindley, S., and Shirayama, Y.: Assessing nature's contributions to people, Science, 359, 270-272, https://doi.org/10.1126/science.aap8826, 2018.

Dufresne, J.-L., Foujols, M.-A., Denvil, S., Caubel, A., Marti, O., Aumont, O., Balkanski, Y., Bekki, S., Bellenger, H., Benshila, R., Bony, S., Bopp, L., Braconnot, P., Brockmann, P., Cadule, P., Cheruy, F., Codron, F., Cozic, A., Cugnet, D., de Noblet, N., Duvel, J.-P., Ethé, C., Fairhead, L., Fichefet, T., Flavoni, S., Friedlingstein, P., Grandpeix, J.-Y., Guez, L., Guilyardi, E., Hauglustaine, D., Hourdin, F., Idelkadi, A., Ghattas, J., Joussaume, S., Kageyama, M., Krinner, G., Labetoulle, S., Lahellec, A., Lefebvre, M.-P., Lefevre, F., Levy, C., Li, Z. X., Lloyd, J., Lott, F., Madec, G., Mancip, M., Marchand, M., Masson, S., Meurdesoif, Y., Mignot, J., Musat, I., Parouty, S., Polcher, J., Rio, C., Schulz, M., Swingedouw, D., Szopa, S., Talandier, C., Terray, P., Viovy, N., and Vuichard, N.: Climate change projections using the IPSL-CM5 Earth System Model: from CMIP3 to CMIP5,
Clim. Dynam., 40, 2123-2165, https://doi.org/10.1007/s00382012-1636-1, 2013.

Elith, J. and Leathwick, J. R.: Species Distribution Models: Ecological Explanation and Prediction Across Space and Time, Annu. Rev. Ecol. Evol. S., 40, 677-697, https://doi.org/10.1146/annurev.ecolsys.110308.120159, 2009.

Ferrier, S., Powell, G. V. N., Richardson, K. S., Manion, G., Overton, J. M., Allnutt, T. F., Cameron, S. E., Mantle, K., Burgess, N. D., Faith, D. P., Lamoreux, J. F., Kier, G., Hijmans, R. J., Funk, V. A., Cassis, G. A., Fisher, B. L., Flemons, P., Lees, D., Lovett, J. C., and Van Rompaey, R. S. A. R.: Mapping More of Terrestrial Biodiversity for Global Conservation Assessment, BioScience, 54, 1101, https://doi.org/10.1641/00063568(2004)054[1101:MMOTBF]2.0.CO;2, 2004.

Ferrier, S., Manion, G., Elith, J., and Richardson, K.: Using generalized dissimilarity modelling to analyse and predict patterns of beta diversity in regional biodiversity assessment, Divers. Distrib., 13, 252-264, https://doi.org/10.1111/j.14724642.2007.00341.x, 2007.

Fick, S. E. and Hijmans, R. J.: WorldClim 2: new 1-km spatial resolution climate surfaces for global land areas: New climate surface for global land areas, Int. J. Climatol., 37, 4302-4315, https://doi.org/10.1002/joc.5086, 2017.

Fourcade, Y.: Comparing species distributions modelled from occurrence data and from expert-based range maps. Implication for predicting range shifts with climate change, Ecological Informatics, 36, 8-14, https://doi.org/10.1016/j.ecoinf.2016.09.002, 2016.

Frieler, K., Levermann, A., Elliott, J., Heinke, J., Arneth, A., Bierkens, M. F. P., Ciais, P., Clark, D. B., Deryng, D., Döll, P., Falloon, P., Fekete, B., Folberth, C., Friend, A. D., Gellhorn, C., Gosling, S. N., Haddeland, I., Khabarov, N., Lomas, M., Masaki, Y., Nishina, K., Neumann, K., Oki, T., Pavlick, R., Ruane, A. C., Schmid, E., Schmitz, C., Stacke, T., Stehfest, E., Tang, Q., Wisser, D., Huber, V., Piontek, F., Warszawski, L., Schewe, J., Lotze-Campen, H., and Schellnhuber, H. J.: A framework for the cross-sectoral integration of multi-model impact projections: land use decisions under climate impacts uncertainties, Earth Syst. Dynam., 6, 447-460, https://doi.org/10.5194/esd-6447-2015, 2015.

Frieler, K., Lange, S., Piontek, F., Reyer, C. P. O., Schewe, J., Warszawski, L., Zhao, F., Chini, L., Denvil, S., Emanuel, K., Geiger, T., Halladay, K., Hurtt, G., Mengel, M., Murakami, D., Ostberg, S., Popp, A., Riva, R., Stevanovic, M., Suzuki, T., Volkholz, J., Burke, E., Ciais, P., Ebi, K., Eddy, T. D., Elliott, J., Galbraith, E., Gosling, S. N., Hattermann, F., Hickler, T., Hinkel, J., Hof, C., Huber, V., Jägermeyr, J., Krysanova, V., Marcé, R., Müller Schmied, H., Mouratiadou, I., Pierson, D., Tittensor, D. P., Vautard, R., van Vliet, M., Biber, M. F., Betts, R. A., Bodirsky, B. L., Deryng, D., Frolking, S., Jones, C. D., Lotze, H. K., LotzeCampen, H., Sahajpal, R., Thonicke, K., Tian, H., and Yamagata, Y.: Assessing the impacts of $1.5^{\circ} \mathrm{C}$ global warming - simulation protocol of the Inter-Sectoral Impact Model Intercomparison Project (ISIMIP2b), Geosci. Model Dev., 10, 4321-4345, https://doi.org/10.5194/gmd-10-4321-2017, 2017.

Frischknecht, R., Fantke, P., Tschümperlin, L., Niero, M., Antón, A., Bare, J., Boulay, A.-M., Cherubini, F., Hauschild, M. Z., Henderson, A., Levasseur, A., McKone, T. E., Michelsen, O., Canals, L. M., Pfister, S., Ridoutt, B., Rosenbaum, R. K., Verones, F., 
Vigon, B., and Jolliet, O.: Global guidance on environmental life cycle impact assessment indicators: progress and case study, Int. J. Life Cycle Ass., 21, 429-442, https://doi.org/10.1007/s11367015-1025-1, 2016.

Fujimori, S., Hasegawa, T., Masui, T., Takahashi, K., Herran, D. S., Dai, H., Hijioka, Y., and Kainuma, M.: SSP3: AIM implementation of Shared Socioeconomic Pathways, Global Environ. Chang., 42, 268-283, https://doi.org/10.1016/j.gloenvcha.2016.06.009, 2017.

Graham, C. T., Wilson, M. W., Gittings, T., Kelly, T. C., Irwin, S., Quinn, J. L., and O'Halloran, J.: Implications of afforestation for bird communities: the importance of preceding land-use type, Biodivers. Conserv., 26, 3051-3071, https://doi.org/10.1007/s10531-015-0987-4, 2017.

Guannel, G., Arkema, K., Ruggiero, P., Verutes, G., and Bianchi, C. N. (Eds.): The Power of Three: Coral Reefs, Seagrasses and Mangroves Protect Coastal Regions and Increase Their Resilience, PLOS ONE, 11, e0158094, https://doi.org/10.1371/journal.pone.0158094, 2016.

Guerra, C. A., Maes, J., Geijzendorffer, I., and Metzger, M. J.: An assessment of soil erosion prevention by vegetation in Mediterranean Europe: Current trends of ecosystem service provision, Ecol. Indic., 60, 213-222, https://doi.org/10.1016/j.ecolind.2015.06.043, 2016.

Guisan, A. and Thuiller, W.: Predicting species distribution: offering more than simple habitat models, Ecol. Lett., 8, 993-1009, https://doi.org/10.1111/j.1461-0248.2005.00792.x, 2005.

Guisan, A. and Zimmermann, N. E.: Predictive habitat distribution models in ecology, Ecol. Model., 135, 147-186, https://doi.org/10.1016/S0304-3800(00)00354-9, 2000.

Harfoot, M., Tittensor, D. P., Newbold, T., McInerny, G., Smith, M. J., and Scharlemann, J. P. W.: Integrated assessment models for ecologists: the present and the future: Integrated assessment models for ecologists, Global Ecol. Biogeogr., 23, 124143, https://doi.org/10.1111/geb.12100, 2014a.

Harfoot, M. B. J., Newbold, T., Tittensor, D. P., Emmott, S., Hutton, J., Lyutsarev, V., Smith, M. J., Scharlemann, J. P. W., Purves, D. W., and Loreau, M. (Eds.): Emergent Global Patterns of Ecosystem Structure and Function from a Mechanistic General Ecosystem Model, PLoS Biol., 12, e1001841, https://doi.org/10.1371/journal.pbio.1001841, 2014b.

Haverd, V., Smith, B., Nieradzik, L., Briggs, P. R., Woodgate, W., Trudinger, C. M., Canadell, J. G., and Cuntz, M.: A new version of the CABLE land surface model (Subversion revision r4601) incorporating land use and land cover change, woody vegetation demography, and a novel optimisation-based approach to plant coordination of photosynthesis, Geosci. Model Dev., 11, 29953026, https://doi.org/10.5194/gmd-11-2995-2018, 2018.

Heinimann, A., Mertz, O., Frolking, S., Egelund Christensen, A., Hurni, K., Sedano, F., Parsons Chini, L., Sahajpal, R., Hansen, M., Hurtt, G., and Poulter, B. (Eds.): A global view of shifting cultivation: Recent, current, and future extent, PLOS ONE, 12, e0184479, https://doi.org/10.1371/journal.pone.0184479, 2017.

Hempel, S., Frieler, K., Warszawski, L., Schewe, J., and Piontek, F.: A trend-preserving bias correction - the ISI-MIP approach, Earth Syst. Dynam., 4, 219-236, https://doi.org/10.5194/esd-4219-2013, 2013.
Hijmans, R. J., Cameron, S. E., Parra, J. L., Jones, P. G., and Jarvis, A.: WorldClim Global Climate Data Version 1, available at: http: //worldclim.org/version1, last access: 20 November 2017.

Hirsch, T. and Secretariat of the Convention on Biological Diversity (Eds.): Global biodiversity outlook 3, Secretariat of the Convention on Biological Diversity, Montreal, Quebec, Canada, 2010.

Hoskins, A. J., Harwood, T. D., Ware, C., Williams, K. J., Perry, J. J., Ota, N., Croft, J. R., Yeates, D. K., Jetz, W., Golebiewski, M., Purvis, A., and Ferrier, S.: Supporting global biodiversity assessment through high-resolution macroecological modelling: Methodological underpinnings of the BILBI framework, BioRxiv http://biorxiv.org/cgi/content/short/309377v1, in preparation, last access: 28 October 2018.

Hudson, L., Newbold, T., Contu, S., Hill, S., Lysenko, I., De Palma, A., Phillips, H., Senior, R., Bennett, D., Booth, H., Choimes, A., Correia, D., Day, J., Echeverría-Londoño, S., Garon, M., Harrison, M., Ingram, D., Jung, M., Kemp, V., Kirkpatrick, L., Martin, C., Pan, Y., White, H., Aben, J., Abrahamczyk, S., Adum, G., Aguilar-Barquero, V., Aizen, M., Ancrenaz, M., ArbeláezCortés, E., Armbrecht, I., Azhar, B., Azpiroz, A., Baeten, L. Báldi, A., Banks, J., Barlow, J., Batáry, P., Bates, A., Bayne, E., Beja, P., Berg, Å., Berry, N., Bicknell, J., Bihn, J., BöhningGaese, K., Boekhout, T., Boutin, C., Bouyer, J., Brearley, F., Brito, I., Brunet, J., Buczkowski, G., Buscardo, E., Cabra-García, J., Calvño-Cancela, M., Cameron, S., Cancello, E., Carrijo, T., Carvalho, A., Castro, H., Castro-Luna, A., Cerda, R., Cerezo, A., Chauvat, M., Clarke, F., Cleary, D., Connop, S., D'Aniello, B., da Silva, P., Darvill, B., Dauber, J., Dejean, A., Diekötter, T., Dominguez-Haydar, Y., Dormann, C., Dumont, B., Dures, S., Dynesius, M., Edenius, L., Elek, Z., Entling, M., Farwig, N., Fayle, T., Felicioli, A., Felton, A., Ficetola, G., Filgueiras, B., Fonte, S., Fraser, L., Fukuda, D., Furlani, D., Ganzhorn, J., Garden, J., Gheler-Costa, C., Giordani, P., Giordano, S., Gottschalk, M., Goulson, D., Gove, A., Grogan, J., Hanley, M., Hanson, T., Hashim, N., Hawes, J., Hébert, C., Helden, A., Henden, J., Hernández, L., Herzog, F., Higuera-Diaz, D., Hilje, B., Horgan, F., Horváth, R., Hylander, K., Isaacs-Cubides, P., Ishitani, M., Jacobs, C., Jaramillo, V., Jauker, B., Jonsell, M., Jung, T., Kapoor, V., Kati, V., Katovai, E., Kessler, M., Knop, E., Kolb, A., Krösi, Á., Lachat, T., Lantschner, V., Le Féon, V., LeBuhn, G., Légaré, J., Letcher, S., Littlewood, N., López-Quintero, C., Louhaichi, M., Lövei, G., Lucas-Borja, M., Luja, V., Maeto, K., Magura, T., Mallari, N., Marin-Spiotta, E., Marshall, E., Martínez, E., Mayfield, M., Mikusinski, G., Milder, J., Miller, J., Morales, C., Muchane, M., Muchane, M., Naidoo, R., Nakamura, A., Naoe, S., Nates-Parra, G., Navarrete Gutierrez, D., Neuschulz, E., Noreika, N., Norfolk, O., Noriega, J., Nöske, N., O’Dea, N., Oduro, W., Ofori-Boateng, C., Oke, C., Osgathorpe, L., Paritsis, J., Parra-H, A., Pelegrin, N., Peres, C., Persson, A., Petanidou, T., Phalan, B., Philips, T., Poveda, K., Power, E., Presley, S., Proença, V., Quaranta, M., Quintero, C., RedpathDowning, N., Reid, J., Reis, Y., Ribeiro, D., Richardson, B., Richardson, M., Robles, C., Römbke, J., Romero-Duque, L., Rosselli, L., Rossiter, S., Roulston, T., Rousseau, L., Sadler, J., Sáfián, S., Saldaña-Vázquez, R., Samnegård, U., Schüepp, C., Schweiger, O., Sedlock, J., Shahabuddin, G., Sheil, D., Silva, F., Slade, E., Smith-Pardo, A., Sodhi, N., Somarriba, E., Sosa, R., Stout, J., Struebig, M., Sung, Y., Threlfall, C., Tonietto, R., Tóthmérész, B., Tscharntke, T., Turner, E., Tylianakis, J., Vanbergen, 
A., Vassilev, K., Verboven, H., Vergara, C., Vergara, P., Verhulst, J., Walker, T., Wang, Y., Watling, J., Wells, K., Williams, C., Willig, M., Woinarski, J., Wolf, J., Woodcock, B., Yu, D., Zaitsev, A., Collen, B., Ewers, R., Mace, G., Purves, D., Scharlemann, J., and Purvis, A.: The PREDICTS database: a global database of how local terrestrial biodiversity responds to human impacts, Ecol. Evol., 4, 4701-4735, https://doi.org/10.1002/ece3.1303, 2014.

Hudson, L. N., Newbold, T., Contu, S., et al.: The 2016 release of the PREDICTS database, https://doi.org/10.5519/0066354, 2016.

Hudson, L. N., Newbold, T., Contu, S., Hill, S. L. L., Lysenko, I., De Palma, A., Phillips, H. R. P., Alhusseini, T. I., Bedford, F. E., Bennett, D. J., Booth, H., Burton, V. J., Chng, C. W. T., Choimes, A., Correia, D. L. P., Day, J., Echeverría-Londoño, S., Emerson, S. R., Gao, D., Garon, M., Harrison, M. L. K., Ingram, D. J., Jung, M., Kemp, V., Kirkpatrick, L., Martin, C. D., Pan, Y., PaskHale, G. D., Pynegar, E. L., Robinson, A. N., Sanchez-Ortiz, K., Senior, R. A., Simmons, B. I., White, H. J., Zhang, H., Aben, J., Abrahamczyk, S., Adum, G. B., Aguilar-Barquero, V., Aizen, M. A., Albertos, B., Alcala, E. L., del Mar Alguacil, M., Alignier, A., Ancrenaz, M., Andersen, A. N., Arbeláez-Cortés, E., Armbrecht, I., Arroyo-Rodríguez, V., Aumann, T., Axmacher, J. C., Azhar, B., Azpiroz, A. B., Baeten, L., Bakayoko, A., Báldi, A., Banks, J. E., Baral, S. K., Barlow, J., Barratt, B. I. P., Barrico, L., Bartolommei, P., Barton, D. M., Basset, Y., Batáry, P., Bates, A. J., Baur, B., Bayne, E. M., Beja, P., Benedick, S., Berg, Å., Bernard, H., Berry, N. J., Bhatt, D., Bicknell, J. E., Bihn, J. H., Blake, R. J., Bobo, K. S., Bóçon, R., Boekhout, T., Böhning-Gaese, K., Bonham, K. J., Borges, P. A. V., Borges, S. H., Boutin, C., Bouyer, J., Bragagnolo, C., Brandt, J. S., Brearley, F. Q., Brito, I., Bros, V., Brunet, J., Buczkowski, G., Buddle, C. M., Bugter, R., Buscardo, E., Buse, J., Cabra-García, J., Cáceres, N. C., et al.: The database of the PREDICTS (Projecting Responses of Ecological Diversity In Changing Terrestrial Systems) project, Ecol. Evol., 7, 145-188, https://doi.org/10.1002/ece3.2579, 2017.

Hurtt, G., Chini, L., Sahajpal, R., Frolking, S., Calvin, K., Fujimori, S., Klein Goldewijk, K., Hasegawa, T., Havlik, P., Lawrence, D., Lawrence, P., Popp, A., Stehfest, E., van Vuuren, D., and Zhang, X.: Land-Use Harmonization 2, available at: http://luh.umd.edu/ data.shtml, last access: 21 December 2017.

Hurtt, G., Chini, L., Sahajpal, R., Frolking, S., Calvin, K., Fujimori, S., Klein Goldewijk, K., Hasegawa, T., Havlik, P., Lawrence, D., Lawrence, P., Popp, A., Stehfest, E., van Vuuren, D., and Zhang, $\mathrm{X}$.: Harmonization of global land-use change and management for the period 850-2100, in preparation, 2018.

Hurtt, G. C., Chini, L. P., Frolking, S., Betts, R. A., Feddema, J., Fischer, G., Fisk, J. P., Hibbard, K., Houghton, R. A., Janetos, A., Jones, C. D., Kindermann, G., Kinoshita, T., Klein Goldewijk, K., Riahi, K., Shevliakova, E., Smith, S., Stehfest, E., Thomson, A., Thornton, P., van Vuuren, D. P., and Wang, Y. P.: Harmonization of land-use scenarios for the period 1500-2100: 600 years of global gridded annual land-use transitions, wood harvest, and resulting secondary lands, Climatic Change, 109, $117-$ 161, https://doi.org/10.1007/s10584-011-0153-2, 2011.

Inter-sectoral Impact Model Intercomparison Project Output Data: available at: https://www.isimip.org/outputdata/, last access: 20 October 2017.
IPBES: The methodological assessment report on scenarios and models of biodiversity and ecosystem services, edited by: Ferrier, S., Ninan, K. N., Leadley, P., Alkemade, R., Acosta, L. A., Akçakaya, H. R., Brotons, L., Cheung, W. W. L., Christensen, V., Harhash, K. A., Kabubo-Mariara, J., Lundquist, C., Obersteiner, M., Pereira, H. M., Peterson, G., Pichs-Madruga, R., Ravindranath, N., Rondinini, C., and Wintle, B. A., Secretariat of the Intergovernmental Science-Policy Platform on Biodiversity and Ecosystem Services, Bonn, Germany, 348 pp., 2016.

Janse, J. H., Kuiper, J. J., Weijters, M. J., Westerbeek, E. P., Jeuken, M. H. J. L., Bakkenes, M., Alkemade, R., Mooij, W. M. and Verhoeven, J. T. A.: GLOBIO-Aquatic, a global model of human impact on the biodiversity of inland aquatic ecosystems, Environ. Sci. Policy, 48, 99-114, https://doi.org/10.1016/j.envsci.2014.12.007, 2015.

Janse, J. H., Bakkenes, M., and Meijer, J.: Globio-Aquatic, Technical model description v. 1.3, PBL publication 2829, The Hague, PBL Netherlands Environmental Assessment Agency, 2016.

Jantz, S. M., Barker, B., Brooks, T. M., Chini, L. P., Huang, Q., Moore, R. M., Noel, J., and Hurtt, G. C.: Future habitat loss and extinctions driven by land-use change in biodiversity hotspots under four scenarios of climate-change mitigation: $\mathrm{Fu}-$ ture Habitat Loss and Extinctions, Conserv. Biol., 29, 1122 1131, https://doi.org/10.1111/cobi.12549, 2015.

Jetz, W., Wilcove, D. S., Dobson, A. P., and Mace, G. M. (Eds.): Projected Impacts of Climate and Land-Use Change on the Global Diversity of Birds, PLoS Biol., 5, e157, https://doi.org/10.1371/journal.pbio.0050157, 2007.

Johnson, J. A., Runge, C. F., Senauer, B., Foley, J., and Polasky, S.: Global agriculture and carbon tradeoffs, P. Natl. Acad. Sci. USA, 111, 12342-12347, https://doi.org/10.1073/pnas.1412835111, 2014.

Johnson, J. A., Runge, C. F., Senauer, B., and Polasky, S.: Global Food Demand and Carbon-Preserving Cropland Expansion under Varying Levels of Intensification, Land Econ., 92, 579-592, https://doi.org/10.3368/le.92.4.579, 2016.

Jungclaus, J. H., Bard, E., Baroni, M., Braconnot, P., Cao, J., Chini, L. P., Egorova, T., Evans, M., González-Rouco, J. F., Goosse, H., Hurtt, G. C., Joos, F., Kaplan, J. O., Khodri, M., Klein Goldewijk, K., Krivova, N., LeGrande, A. N., Lorenz, S. J., Luterbacher, J., Man, W., Maycock, A. C., Meinshausen, M., Moberg, A., Muscheler, R., Nehrbass-Ahles, C., Otto-Bliesner, B. I., Phipps, S. J., Pongratz, J., Rozanov, E., Schmidt, G. A., Schmidt, H., Schmutz, W., Schurer, A., Shapiro, A. I., Sigl, M., Smerdon, J. E., Solanki, S. K., Timmreck, C., Toohey, M., Usoskin, I. G., Wagner, S., Wu, C.-J., Yeo, K. L., Zanchettin, D., Zhang, Q., and Zorita, E.: The PMIP4 contribution to CMIP6 - Part 3: The last millennium, scientific objective, and experimental design for the PMIP4 past 1000 simulations, Geosci. Model Dev., 10, 40054033, https://doi.org/10.5194/gmd-10-4005-2017, 2017.

Knorr, W., Arneth, A., and Jiang, L.: Demographic controls of future global fire risk, Nat. Clim. Change, 6, 781-785, https://doi.org/10.1038/nclimate2999, 2016.

Kriegler, E., Bauer, N., Popp, A., Humpenöder, F., Leimbach, M., Strefler, J., Baumstark, L., Bodirsky, B. L., Hilaire, J., Klein, D., Mouratiadou, I., Weindl, I., Bertram, C., Dietrich, J.-P., Luderer, G., Pehl, M., Pietzcker, R., Piontek, F., Lotze-Campen, H., Biewald, A., Bonsch, M., Giannousakis, A., Kreidenweis, U., Müller, C., Rolinski, S., Schultes, A., Schwanitz, J., Stevanovic, 
M., Calvin, K., Emmerling, J., Fujimori, S., and Edenhofer, O.: Fossil-fueled development (SSP5): An energy and resource intensive scenario for the 21st century, Global Environ. Chang., 42, 297-315, https://doi.org/10.1016/j.gloenvcha.2016.05.015, 2017.

Lawrence, D. M., Hurtt, G. C., Arneth, A., Brovkin, V., Calvin, K. V., Jones, A. D., Jones, C. D., Lawrence, P. J., de NobletDucoudré, N., Pongratz, J., Seneviratne, S. I., and Shevliakova, E.: The Land Use Model Intercomparison Project (LUMIP) contribution to CMIP6: rationale and experimental design, Geosci. Model Dev., 9, 2973-2998, https://doi.org/10.5194/gmd-9-29732016, 2016.

Leadley, P. W., Krug, C. B., Alkemade, R., Pereira, H. M., Sumaila U. R., Walpole, M., Marques, A., Newbold, T., Teh, L. S. L., van Kolck, J., Bellard, C., Januchowski-Hartley, S. R., and Mumby, P. J.: Progress towards the Aichi Biodiversity Targets: An Assessment of Biodiversity Trends, Policy Scenarios and Key Actions, Secretariat of the Convention on Biological Diversity, Montreal, Canada, Technical Series 78, 500 pp., 2014.

Lehsten, V., Sykes, M. T., Scott, A. V., Tzanopoulos, J., Kallimanis, A., Mazaris, A., Verburg, P. H., Schulp, C. J. E., Potts, S. G., and Vogiatzakis, I.: Disentangling the effects of land-use change, climate and $\mathrm{CO}_{2}$ on projected future European habitat types: Disentangling the drivers of habitat change, Global Ecol. Biogeogr., 24, 653-663, https://doi.org/10.1111/geb.12291, 2015.

Lindeskog, M., Arneth, A., Bondeau, A., Waha, K., Seaquist, J., Olin, S., and Smith, B.: Implications of accounting for land use in simulations of ecosystem carbon cycling in Africa, Earth Syst. Dynam., 4, 385-407, https://doi.org/10.5194/esd-4-3852013, 2013.

Martins, I. S. and Pereira, H. M.: Improving extinction projections across scales and habitats using the countryside species-area relationship, Sci. Rep.-UK, 7, 12899, https://doi.org/10.1038/s41598-017-13059-y, 2017.

Maxwell, S. L., Fuller, R. A., Brooks, T. M., and Watson, J. E. M.: Biodiversity: The ravages of guns, nets and bulldozers, Nature, 536, 143-145, https://doi.org/10.1038/536143a, 2016.

McSweeney, C. F. and Jones, R. G.: How representative is the spread of climate projections from the 5 CMIP5 GCMs used in ISI-MIP?, Clim. Serv., 1, 24-29, https://doi.org/10.1016/j.cliser.2016.02.001, 2016.

Meinshausen, M., Wigley, T. M. L., and Raper, S. C. B.: Emulating atmosphere-ocean and carbon cycle models with a simpler model, MAGICC6 - Part 2: Applications, Atmos. Chem. Phys., 11, 1457-1471, https://doi.org/10.5194/acp-111457-2011, 2011a.

Meinshausen, M., Raper, S. C. B., and Wigley, T. M. L.: Emulating coupled atmosphere-ocean and carbon cycle models with a simpler model, MAGICC6 - Part 1: Model description and calibration, Atmos. Chem. Phys., 11, 1417-1456, https://doi.org/10.5194/acp-11-1417-2011, 2011b.

Merow, C., Smith, M. J., and Silander, J. A.: A practical guide to MaxEnt for modeling species' distributions: what it does, and why inputs and settings matter, Ecography, 36, 1058-1069, https://doi.org/10.1111/j.1600-0587.2013.07872.x, 2013.

Millennium Ecosystem Assessment (Program) (Ed.): Ecosystems and human well-being: synthesis, Island Press, Washington, DC, 2005 .
Monfreda, C., Ramankutty, N., and Foley, J. A.: Farming the planet: 2. Geographic distribution of crop areas, yields, physiological types, and net primary production in the year 2000: Global crop areas and yields in 2000, Global Biogeochem. Cy., 22, GB1022, https://doi.org/10.1029/2007GB002947, 2008.

Moss, R. H., Edmonds, J. A., Hibbard, K. A., Manning, M. R., Rose, S. K., van Vuuren, D. P., Carter, T. R., Emori, S., Kainuma, M., Kram, T., Meehl, G. A., Mitchell, J. F. B., Nakicenovic, N., Riahi, K., Smith, S. J., Stouffer, R. J., Thomson, A. M., Weyant, J. P., and Wilbanks, T. J.: The next generation of scenarios for climate change research and assessment, Nature, 463, 747-756, https://doi.org/10.1038/nature08823, 2010.

Newbold, T., Hudson, L. N., Arnell, A. P., Contu, S., De Palma, A., Ferrier, S., Hill, S. L. L., Hoskins, A. J., Lysenko, I., Phillips, H. R. P., Burton, V. J., Chng, C. W. T., Emerson, S., Gao, D., PaskHale, G., Hutton, J., Jung, M., Sanchez-Ortiz, K., Simmons, B. I., Whitmee, S., Zhang, H., Scharlemann, J. P. W., and Purvis, A.: Has land use pushed terrestrial biodiversity beyond the planetary boundary? A global assessment, Science, 353, 288-291, https://doi.org/10.1126/science.aaf2201, 2016.

Ohashi, H., Hasegawa, T., Hirata, A., Fujimori, S., Takahashi, K., Tsuyama, I., Nakao, K., Kominami, Y., Tanaka, N., Hijioka, Y., and Matsui, T.: Biodiversity can benefit from long-term climate mitigation regardless of land-based measures, submitted, 2018.

Olin, S., Schurgers, G., Lindeskog, M., Wårlind, D., Smith, B., Bodin, P., Holmér, J., and Arneth, A.: Modelling the response of yields and tissue $\mathrm{C}: \mathrm{N}$ to changes in atmospheric $\mathrm{CO}_{2}$ and $\mathrm{N}$ management in the main wheat regions of western Europe, Biogeosciences, 12, 2489-2515, https://doi.org/10.5194/bg-122489-2015, 2015.

O’Neill, B. C., Kriegler, E., Riahi, K., Ebi, K. L., Hallegatte, S., Carter, T. R., Mathur, R. and van Vuuren, D. P.: A new scenario framework for climate change research: the concept of shared socioeconomic pathways, Climatic Change, 122, 387400, https://doi.org/10.1007/s10584-013-0905-2, 2014.

O’Neill, B. C., Tebaldi, C., van Vuuren, D. P., Eyring, V., Friedlingstein, P., Hurtt, G., Knutti, R., Kriegler, E., Lamarque, J.-F., Lowe, J., Meehl, G. A., Moss, R., Riahi, K., and Sanderson, B. M.: The Scenario Model Intercomparison Project (ScenarioMIP) for CMIP6, Geosci. Model Dev., 9, 3461-3482, https://doi.org/10.5194/gmd-9-3461-2016, 2016.

O’Neill, B. C., Kriegler, E., Ebi, K. L., Kemp-Benedict, E., Riahi, K., Rothman, D. S., van Ruijven, B. J., van Vuuren, D. P., Birkmann, J., Kok, K., Levy, M., and Solecki, W.: The roads ahead: Narratives for shared socioeconomic pathways describing world futures in the 21st century, Global Environ. Chang., 42, 169-180, https://doi.org/10.1016/j.gloenvcha.2015.01.004, 2017.

Pecl, G. T., Araújo, M. B., Bell, J. D., Blanchard, J., Bonebrake, T. C., Chen, I.-C., Clark, T. D., Colwell, R. K., Danielsen, F., Evengård, B., Falconi, L., Ferrier, S., Frusher, S., Garcia, R. A., Griffis, R. B., Hobday, A. J., Janion-Scheepers, C., Jarzyna, M. A., Jennings, S., Lenoir, J., Linnetved, H. I., Martin, V. Y., McCormack, P. C., McDonald, J., Mitchell, N. J., Mustonen, T., Pandolfi, J. M., Pettorelli, N., Popova, E., Robinson, S. A., Scheffers, B. R., Shaw, J. D., Sorte, C. J. B., Strugnell, J. M., Sunday, J. M., Tuanmu, M.-N., Vergés, A., Villanueva, C., Wernberg, T., Wapstra, E., and Williams, S. E.: Biodiversity redistribution under climate change: Impacts on ecosystems and human well-being, 
Science, 355, eaai9214, https://doi.org/10.1126/science.aai9214, 2017.

Pereira, H. M., Leadley, P. W., Proenca, V., Alkemade, R., Scharlemann, J. P. W., Fernandez-Manjarres, J. F., Araujo, M. B., Balvanera, P., Biggs, R., Cheung, W. W. L., Chini, L., Cooper, H. D., Gilman, E. L., Guenette, S., Hurtt, G. C., Huntington, H. P., Mace, G. M., Oberdorff, T., Revenga, C., Rodrigues, P., Scholes, R. J., Sumaila, U. R., and Walpole, M.: Scenarios for Global Biodiversity in the 21st Century, Science, 330, 14961501, https://doi.org/10.1126/science.1196624, 2010.

Popp, A., Calvin, K., Fujimori, S., Havlik, P., Humpenöder, F., Stehfest, E., Bodirsky, B. L., Dietrich, J. P., Doelmann, J. C., Gusti, M., Hasegawa, T., Kyle, P., Obersteiner, M., Tabeau, A., Takahashi, K., Valin, H., Waldhoff, S., Weindl, I., Wise, M., Kriegler, E., Lotze-Campen, H., Fricko, O., Riahi, K., and Vuuren, D. P. van: Land-use futures in the shared socioeconomic pathways, Global Environ. Chang., 42, 331-345, https://doi.org/10.1016/j.gloenvcha.2016.10.002, 2017.

Poulter, B., Frank, D. C., Hodson, E. L., and Zimmermann, N. E.: Impacts of land cover and climate data selection on understanding terrestrial carbon dynamics and the $\mathrm{CO}_{2}$ airborne fraction, Biogeosciences, 8, 2027-2036, https://doi.org/10.5194/bg8-2027-2011, 2011.

Prentice, I. C., Bondeau, A., Cramer, W., Harrison, S. P., Hickler, T., Lucht, W., Sitch, S., Smith, B., Sykes, M. T., Canadell, J. G., Pataki, D. E., and Pitelka, L. F. (Eds.): Dynamic Global Vegetation Modeling: Quantifying Terrestrial Ecosystem Responses to Large-Scale Environmental Change, in Terrestrial Ecosystems in a Changing World, Springer Berlin Heidelberg, Berlin, Heidelberg, 175-192, 2007.

Purvis, A., Newbold, T., De Palma, A., Contu, S., Hill, S. L. L., Sanchez-Ortiz, K., Phillips, H. R. P., Hudson, L. N., Lysenko, I., Börger, L., and Scharlemann, J. P. W.: Modelling and Projecting the Response of Local Terrestrial Biodiversity Worldwide to Land Use and Related Pressures: The PREDICTS Project, in: Advances in Ecological Research, Elsevier, vol. 58, 201-241, 2018.

Rabin, S. S., Melton, J. R., Lasslop, G., Bachelet, D., Forrest, M., Hantson, S., Kaplan, J. O., Li, F., Mangeon, S., Ward, D. S., Yue, C., Arora, V. K., Hickler, T., Kloster, S., Knorr, W., Nieradzik, L., Spessa, A., Folberth, G. A., Sheehan, T., Voulgarakis, A., Kelley, D. I., Prentice, I. C., Sitch, S., Harrison, S., and Arneth, A.: The Fire Modeling Intercomparison Project (FireMIP), phase 1: experimental and analytical protocols with detailed model descriptions, Geosci. Model Dev., 10, 11751197, https://doi.org/10.5194/gmd-10-1175-2017, 2017.

Redhead, J. W., May, L., Oliver, T. H., Hamel, P., Sharp, R., and Bullock, J. M.: National scale evaluation of the InVEST nutrient retention model in the United Kingdom, Sci. Total Environ., 610 611, 666-677, https://doi.org/10.1016/j.scitotenv.2017.08.092, 2018.

Riahi, K., van Vuuren, D. P., Kriegler, E., Edmonds, J., O’Neill, B. C., Fujimori, S., Bauer, N., Calvin, K., Dellink, R., Fricko, O., Lutz, W., Popp, A., Cuaresma, J. C., Kc, S., Leimbach, M., Jiang, L., Kram, T., Rao, S., Emmerling, J., Ebi, K., Hasegawa, T., Havlik, P., Humpenöder, F., Da Silva, L. A., Smith, S., Stehfest, E., Bosetti, V., Eom, J., Gernaat, D., Masui, T., Rogelj, J., Strefler, J., Drouet, L., Krey, V., Luderer, G., Harmsen, M., Takahashi, K., Baumstark, L., Doelman, J. C., Kainuma, M.,
Klimont, Z., Marangoni, G., Lotze-Campen, H., Obersteiner, M., Tabeau, A., and Tavoni, M.: The Shared Socioeconomic Pathways and their energy, land use, and greenhouse gas emissions implications: An overview, Global Environ. Chang., 42, 153168, https://doi.org/10.1016/j.gloenvcha.2016.05.009, 2017.

Rondinini, C., Di Marco, M., Chiozza, F., Santulli, G., Baisero, D., Visconti, P., Hoffmann, M., Schipper, J., Stuart, S. N., Tognelli, M. F., Amori, G., Falcucci, A., Maiorano, L., and Boitani, L.: Global habitat suitability models of terrestrial mammals, Philos. T. Roy. Soc. B Biol., 366, 2633-2641, https://doi.org/10.1098/rstb.2011.0113, 2011.

Rosa, I. M. D., Pereira, H. M., Ferrier, S., Alkemade, R., Acosta, L. A., Akcakaya, R., den Belder, E., Fazel, A. M., Fujimori, S., Harfoot, M., Harhash, K. A., Harrison, P. A., Hauck, J., Hendriks, R. J. J., Hernández, G., Jetz, W., Karlsson-Vinkhuyzen, S. I., Kim, H. J., King, N., Kok, M. T. J., Kolomytsev, G. O., Lazarova, T., Leadley, P., Lundquist, C. J., García Márquez, J., Meyer, C., Navarro, L. M., Nesshöver, C., Ngo, H. T., Ninan, K. N., Palomo, M. G., Pereira, L. M., Peterson, G. D., Pichs, R., Popp, A., Purvis, A., Ravera, F., Rondinini, C., Sathyapalan, J., Schipper, A. M., Seppelt, R., Settele, J., Sitas, N., and van Vuuren, D.: Multiscale scenarios for nature futures, Nat. Ecol. Evol., 1, 1416-1419, 2017.

Rosenzweig, C., Arnell, N. W., Ebi, K. L., Lotze-Campen, H., Raes, F., Rapley, C., Smith, M. S., Cramer, W., Frieler, K., Reyer, C. P. O., Schewe, J., van Vuuren, D., and Warszawski, L.: Assessing inter-sectoral climate change risks: the role of ISIMIP, Environ. Res. Lett., 12, 010301, https://doi.org/10.1088/17489326/12/1/010301, 2017

Sala, O. E.: Global Biodiversity Scenarios for the Year 2100, Science, 287, 1770-1774, https://doi.org/10.1126/science.287.5459.1770, 2000.

Schipper, A. M., Bakkenes, M., Meijer, J. R., Alkemade, R., and Huijbregts, M. J.: The GLOBIO model. A technical description of version 3.5. PBL publication 2369, The Hague, PBL Netherlands Environmental Assessment Agency, 2016.

Schulp, C. J. E., Alkemade, R., Klein Goldewijk, K., and Petz, K.: Mapping ecosystem functions and services in Eastern Europe using global-scale data sets, Int. J. Biodivers. Sci. Ecosyst. Serv. Manag., 8, 156-168, https://doi.org/10.1080/21513732.2011.645880, 2012.

Secretariat of the Convention on Biological Diversity and United Nations Environment Programme (Eds.): Global biodiversity outlook 4: a mid-term assessment of progress towards the implementation of the strategic plan for biodiversity 2011-2020, Secretariat for the Convention on Biological Diversity, Montreal, Quebec, Canada, 2014.

Settele, J., Scholes, R., Betts, R. A., Bunn, S., Leadley, P., Nepstad, D., Overpeck, J. T., Taboada, M. A., Fischlin, A., Moreno, J. M., Root, T., Musche, M., and Winter, M.: Terrestrial and Inland water systems, in: Climate Change 2014 Impacts, Adaptation and Vulnerability: Part A: Global and Sectoral Aspects, Cambridge University Press, 271-360, https://doi.org/10.1017/CBO9781107415379.009, 2015.

Sharp, R., Tallis, H. T., Ricketts, T., Guerry, A. D., Wood, S. A., Chaplin-Kramer, R., Nelson, E., Ennaanay, D., Wolny, S., Olwero, N., Vigerstol, K., Pennington, D., Mendoza, G., Aukema, J., Foster, J., Forrest, J., Cameron, D., Arkema, K., Lonsdorf, E., Kennedy, C., Verutes, G., Kim, C. K., Guannel, G., Papenfus, 
M., Toft, J., Marsik, M., Bernhardt, J., Griffin, R., Glowinski, K., Chaumont, N., Perelman, A., Lacayo, M., Mandle, L., Hamel, P., Vogl, A. L., Rogers, L., Bierbower, W., Denu, D., and Douglass, J.: InVEST + VERSION+ User's Guide, The Natural Capital Project, Stanford University, University of Minnesota, The Nature Conservancy, and World Wildlife Fund, 2016.

Sitch, S., Smith, B., Prentice, I. C., Arneth, A., Bondeau, A., Cramer, W., Kaplan, J. O., Levis, S., Lucht, W., Sykes, M. T., Thonicke, K., and Venevsky, S.: Evaluation of ecosystem dynamics, plant geography and terrestrial carbon cycling in the LPJ dynamic global vegetation model, Glob. Change Biol., 9, 161-185, https://doi.org/10.1046/j.1365-2486.2003.00569.x, 2003.

Smith, B., Wårlind, D., Arneth, A., Hickler, T., Leadley, P., Siltberg, J., and Zaehle, S.: Implications of incorporating $\mathrm{N}$ cycling and $\mathrm{N}$ limitations on primary production in an individualbased dynamic vegetation model, Biogeosciences, 11, 20272054, https://doi.org/10.5194/bg-11-2027-2014, 2014.

Stehfest, E., van Vuuren, D., Kram, T., Bouwman, L., Alkemade, R., Bakkenes, M., Biemans, H., Bouwman, A., den Elzen, M., Janse, J., Lucas, P., van Minnen, J., Müller, M., and Prins, A.: Integrated Assessment of Global Environmental Change with IMAGE 3.0. Model description and policy applications, The Hague, PBL Netherlands Environmental Assessment Agency, 2014.

Thuiller, W.: Patterns and uncertainties of species' range shifts under climate change, Glob. Change Biol., 10, 2020-2027, https://doi.org/10.1111/j.1365-2486.2004.00859.x, 2004.

Thuiller, W., Lafourcade, B., Engler, R., and Araújo, M. B.: BIOMOD - a platform for ensemble forecasting of species distributions, Ecography, 32, 369-373, https://doi.org/10.1111/j.16000587.2008.05742.x, 2009.

Thuiller, W., Lavergne, S., Roquet, C., Boulangeat, I., Lafourcade, B., and Araujo, M. B.: Consequences of climate change on the tree of life in Europe, Nature, 470, 531-534, https://doi.org/10.1038/nature09705, 2011.

Thuiller, W., Münkemüller, T., Lavergne, S., Mouillot, D., Mouquet, N., Schiffers, K., Gravel, D., and Holyoak, M. (Eds.): A road map for integrating eco-evolutionary processes into biodiversity models, Ecol. Lett., 16, 94-105, https://doi.org/10.1111/ele.12104, 2013.

Titeux, N., Henle, K., Mihoub, J.-B., Regos, A., Geijzendorffer, I. R., Cramer, W., Verburg, P. H., and Brotons, L.: Biodiversity scenarios neglect future land-use changes, Glob. Change Biol., 22, 2505-2515, https://doi.org/10.1111/gcb.13272, 2016.

Titeux, N., Henle, K., Mihoub, J.-B., Regos, A., Geijzendorffer, I. R., Cramer, W., Verburg, P. H., Brotons, L., and Syphard, A. (Eds.): Global scenarios for biodiversity need to better integrate climate and land use change, Divers. Distrib., 23, 1231-1234, https://doi.org/10.1111/ddi.12624, 2017.

United Nations Environment Programme (UNEP): UNEP-SETAC Life Cycle Initiative: Global Guidance for Life Cycle Impact Assessment Indicators - Volume 1, 2016.
United Nations Environment Programme-World Conservation Monitoring Centre: Dataset combining Exclusive Economic Zones (EEZ, VLIZ 2014) and terrestrial country boundaries (World Vector Shoreline, 3rd Edn., National GeospatialIntelligence Agency), Cambridge (UK), UNEP World Conservation Monitoring Centre, 2015.

van Beek, L. P. H., Wada, Y., and Bierkens, M. F. P.: Global monthly water stress: 1. Water balance and water availability: Global Monthly Water Stress, 1, Water Resour. Res., 47, W07517, https://doi.org/10.1029/2010WR009791, 2011.

van Vuuren, D. P., Edmonds, J., Kainuma, M., Riahi, K., Thomson, A., Hibbard, K., Hurtt, G. C., Kram, T., Krey, V., Lamarque, J.-F., Masui, T., Meinshausen, M., Nakicenovic, N., Smith, S. J., and Rose, S. K.: The representative concentration pathways: an overview, Climatic Change, 109, 5-31, https://doi.org/10.1007/s10584-011-0148-z, 2011.

van Vuuren, D. P., Kriegler, E., O’Neill, B. C., Ebi, K. L., Riahi, K., Carter, T. R., Edmonds, J., Hallegatte, S., Kram, T., Mathur, R., and Winkler, H.: A new scenario framework for Climate Change Research: scenario matrix architecture, Climatic Change, 122 373-386, https://doi.org/10.1007/s10584-013-0906-1, 2014.

van Vuuren, D. P., Stehfest, E., Gernaat, D. E. H. J., Doelman, J. C., van den Berg, M., Harmsen, M., de Boer, H. S., Bouwman, L. F., Daioglou, V., Edelenbosch, O. Y., Girod, B., Kram, T., Lassaletta, L., Lucas, P. L., van Meijl, H., Müller, C., van Ruijven, B. J., van der Sluis, S., and Tabeau, A.: Energy, land-use and greenhouse gas emissions trajectories under a green growth paradigm, Global Environ. Chang., 42, 237-250, https://doi.org/10.1016/j.gloenvcha.2016.05.008, 2017.

Visconti, P., Bakkenes, M., Baisero, D., Brooks, T., Butchart, S. H. M., Joppa, L., Alkemade, R., Di Marco, M., Santini, L., Hoffmann, M., Maiorano, L., Pressey, R. L., Arponen, A., Boitani, L., Reside, A. E., van Vuuren, D. P., and Rondinini, C.: Projecting Global Biodiversity Indicators under Future Development Scenarios: Projecting biodiversity indicators, Conserv. Lett., 9, 5-13, https://doi.org/10.1111/conl.12159, 2016.

Warszawski, L., Frieler, K., Huber, V., Piontek, F., Serdeczny, O., and Schewe, J.: The Inter-Sectoral Impact Model Intercomparison Project (ISI-MIP): Project framework, P. Natl. Acad. Sci. USA, 111, 3228-3232, https://doi.org/10.1073/pnas.1312330110, 2014.

Welbergen, J. A., Klose, S. M., Markus, N., and Eby, P.: Climate change and the effects of temperature extremes on Australian flying-foxes, Philos. T. Roy. Soc. B Biol., 275, 419-425, https://doi.org/10.1098/rspb.2007.1385, 2008. 